\title{
Verification of runoff volume, peak discharge and sediment yield simulated using the ACRU model for bare fallow and sugarcane fields
}

\author{
Daniel Otim ${ }^{1,5}$, Jeff Smithers ${ }^{1,3}$, Aidan Senzanje ${ }^{1}$ and Rianto van Antwerpen ${ }^{2,4}$ \\ 'Agricultural Engineering, School of Engineering, College of Agriculture, Engineering and Science, University of KwaZulu-Natal, \\ Pietermaritzburg, South Africa \\ ${ }^{2}$ South African Sugarcane Research Institute, Mount Edgecombe, South Africa \\ ${ }^{3}$ National Centre for Engineering in Agriculture, University of Southern Queensland, Toowoomba, Australia \\ ${ }^{4}$ Department of Soil, Crops and Climate Sciences, University of the Free State, PO Box 339, Bloemfontein 9300, South Africa \\ ${ }^{5}$ Department of Agricultural Mechanisation and Irrigation Engineering, Busitema University, PO Box 236, Tororo, Uganda
}

\begin{abstract}
The Agricultural Catchments Research Unit (ACRU) model is a daily time step physical-conceptual agrohydrological model with various applications, design hydrology being one of them. Model verification is a measure of model performance and streamflow, soil water content and sediment yield simulated by the ACRU model have been extensively verified against observed data in southern Africa and internationally. The primary objective of this study was to verify simulated runoff volume, peak discharge and sediment yield against observed data from small catchments, under both bare fallow conditions and sugarcane production, which were located at La Mercy in South Africa. The study area comprised 4 research catchments, 101, 102, 103 and 104, monitored both under bare fallow conditions and sugarcane production, with different management practices per catchment. Observed data comprised: daily rainfall, maximum and minimum temperature, A-pan evaporation and runoff for the period 1978-1995, and peak discharge and sediment yield for the period 1984-1995. The data were checked for errors and and inconsistent records excluded from analysis. Runoff volume, peak discharge and sediment yield were simulated with the ACRU model and verified against the respective observed data. In general, the correlations between observed and simulated daily runoff volumes and peak discharge were acceptable (i.e. slopes of regression lines close to unity, $R^{2} \geq$ 0.6 and the Nash-Sutcliffe coefficient of efficiency close to unity). Similarly, the correlation between observed and simulated sediment yield was also good. From the results obtained, it is concluded that the ACRU model is suitable for the simulation of runoff volume, peak discharge and sediment yield from catchments under both bare fallow and sugarcane land cover in South Africa.
\end{abstract}

\section{INTRODUCTION}

The Agricultural Catchments Research Unit (ACRU) model is a daily time step, physicalconceptual agrohydrological model (Schulze, 1975; Schulze et al., 1995; Smithers and Schulze, 1995; Smithers et al., 1996). In addition, the ACRU model is not an optimising model and parameters are estimated from physical characteristics of catchments. It is a multi-purpose model with application in design hydrology, crop yield modelling, reservoir yield simulation, irrigation water demand and supply, and assessment of climate change, land use and management impacts (Schulze et al., 1995; Jewitt and Schulze, 1999). The ACRU model, together with simulated outputs such as streamflow, soil water content and sediment yield, has been extensively verified against observed data in southern Africa and internationally (Schulze, 2011). To verify is to determine the correctness of simulated output through comparison with observed data, hence model verification is a measure of the model's performance (Schulze, 2011). Model verification can be in terms of either absolute output values or in terms of the relative sequences and orders of magnitude of output responses (Lumsden et al., 2003). For simulations using a daily time-step model to be acceptable, the absolute difference between the sum of simulated streamflow and the sum of observed streamflow should be less than $10 \%$, the slope of the regression line of simulated vs observed values should be close to unity and the minimum acceptable coefficient of determination $\left(R^{2}\right)$ should be 0.60 (Schulze and Smithers, 1995). However, model goodness-of-fit is better evaluated by the Nash-Sutcliffe coefficient of efficiency (NSE) (Nash and Sutcliffe, 1970) than the $R^{2}$ because $R^{2}$ is insensitive to additive and proportional differences between model simulations and observations (Harmel et al., 2014). The NSE is a normalised statistic from which the relative magnitude of the residual variance compared to the measured data variance is determined (Nash and Sutcliffe, 1970). The NSE shows how well the plot of observed against simulated data fits the 1:1 line, with NSE values close to unity corresponding to a perfect match of the model to the observed data (AgriMetSoft, 2019). In addition, model performance is examined based on its ability to generate reasonable key statistics like percentiles and extreme values (Rashid et al., 2015), and maintain similarities in shapes and distributions of peaks between observed and simulated values (Kim et al., 2014). Continuous assessment of the accuracy and sensitivity of models is vital in the prioritisation of model structure modifications and the identification of more efficient parameterisations (Merritt et al., 2003).
CORRESPONDENCE

Daniel Otim

EMAIL

danotim@gmail.com

\section{DATES}

Received: 1 April 2019

Accepted: 3 April 2020

\section{KEYWORDS}

ACRU

bare fallow

peak discharge

sediment yield

streamflow

sugarcane

\section{COPYRIGHT}

(๑) The Author(s)

Published under a Creative

Commons Attribution 4.0

International Licence (CC BY 4.0) 
The results reported in this paper are a component of a wider study whose aim is to develop updated design norms for soil and water conservation structures in the sugar industry in South Africa. The nomograph for the design of soil and water conservation structures in the sugar industry in South Africa was developed by Platford (1987), who used long-term annual soil loss simulated using the Universal Soil Loss Equation (USLE). However, erosion occurs on an event basis and Platford (1987) did not conduct any verification on the USLE prior to development of the nomograph. Therefore, the objective of this paper was to verify the runoff volume, peak discharge and sediment yield simulated by the ACRU model against observed data at the La Mercy catchments in South Africa, under both bare fallow and sugarcane land cover conditions and with various management practices.

\section{Simulation of stormflow volume, peak discharge and sediment yield in the ACRU model}

The following sections contain brief overviews of the simulation of stormflow volume, peak discharge and sediment yield used in the ACRU model.

\section{Stormflow volume}

Stormflow is the runoff that is produced from a particular rainfall event, either at or close to the surface in a catchment, and which contributes to stream discharge within that catchment (Schulze, 2011). The response of a catchment to runoff from rainfall events depends on interactions between rainfall intensity, antecedent soil moisture conditions and land cover (Smithers et al., 1996; Maher, 2000). Estimation of stormflow in the ACRU model is based on a modified SCS procedure which employs daily rainfall input as the driving mechanism (Schmidt et al., 1987). The algorithm employed by the ACRU model in the estimation of stormflow is shown in Eq. 1 (Schmidt et al., 1987; Schulze, 1995).

$$
Q_{s}=\frac{\left(P_{g}-I_{a}\right)^{2}}{\left(P_{g}-I_{a}+S\right)} \text { for } P_{g}>I_{a}
$$

where

$Q_{\text {s }}$

$=$ stormflow depth $(\mathrm{mm})$,

$P_{\mathrm{g}}=$ gross daily precipitation amount $(\mathrm{mm})$,

$I_{\mathrm{a}}^{\mathrm{g}}=$ initial abstraction prior to stormflow

commencement $(\mathrm{mm})$, and

$S=$ potential maximum soil water retention $(\mathrm{mm})$.

The initial abstraction prior to stormflow commencement, $I_{\mathrm{a}}(\mathrm{mm})$ is a product of the coefficient of initial abstraction, $(c)$ and potential maximum soil water retention $(S)$, as shown in Eq. 2 .

$$
I_{a}=c S
$$

The storage capacity of a soil and the depth of the underlying layers impact on the timing and magnitude of the flood response to precipitation (Royappen, 2002). Hence, the lower the storage capacity and the shallower the subsurface soil depth limiting layers, the higher the potential flood magnitude and intensity. The effective depth of soil used in the ACRU model for stormflow generation (SMDDEP) attempts to account for various streamflow-generating processes resulting from varying climate, vegetation and soil conditions (Royappen, 2002). However, the SMDDEP variable is difficult to quantify and it has generally been estimated through experience/ calibration, with default values suggested to the ACRU model user (Rowe, 2015).

\section{Peak discharge}

Peak discharge is an important variable in the estimation of sediment yield from a catchment (Schulze, 2011). The peak discharge from a given catchment is linked to the stormflow volume from that catchment; thus the accurate estimation of the stormflow volume is of prime importance in the determination of peak discharge (Schmidt and Schulze, 1984). The equation used in the simulation of peak discharge by the ACRU model from a catchment employs the SCS triangular-shaped unit hydrograph approach (Schulze and Schmidt, 1995) and represents the stormflow hydrograph for an incremental unit depth of stormflow occurring in a unit increment of time, as shown in Eq. 3 (Schulze et al., 2004).

$$
\Delta q_{p}=\frac{0.2083 A \Delta Q}{\frac{\Delta D}{2}+L}
$$

where

$\Delta q_{\mathrm{p}}=$ peak discharge of incremental unit hydrograph $\left(\mathrm{m}^{3} \cdot \mathrm{s}^{-1}\right)$

$\Delta Q=$ incremental storm flow depth $(\mathrm{mm})$

$A=$ catchment area $\left(\mathrm{km}^{2}\right)$

$L=$ catchment lag time (h)

$\Delta D=$ incremental time duration (h)

There are three options for estimating the catchment lag time in ACRU, of which the Schmidt-Schulze lag equation is preferred for use within natural catchments in South Africa (Schmidt and Schulze, 1984; Schulze et al., 1992). The catchment lag time, $L$ (h) is determined from catchment area, $A\left(\mathrm{~km}^{2}\right)$, 2-year return period 30-min rainfall intensity, $i_{30}\left(\mathrm{~mm} \cdot \mathrm{h}^{-1}\right)$, mean annual precipitation, MAP ( $\mathrm{mm}$ ), and average catchment slope, $S(\%)$, as shown in Eq. 4 (Schmidt and Schulze, 1984).

$$
L=\frac{A^{0.35} \mathrm{MAP}^{1.1}}{41.67 S^{0.3} i_{30}^{0.87}}
$$

The catchment lag time, $L(\mathrm{~h})$ is related to the catchment time of concentration, $T_{c}(\mathrm{~h})$, as shown in Eq. 5 (Schulze and Schmidt, 1995).

$$
L=0.6 T_{c}
$$

\section{Sediment yield}

Sediment yield in the ACRU model is simulated using the Modified Universal Soil Loss Equation (MUSLE) (Williams, 1975), which is an empirical equation derived from the Universal Soil Loss Equation (USLE) (Wischmeier and Smith, 1965; Wischmeier and Smith, 1978) through replacement of the rainfall erosivity factor with a storm flow factor (Lorentz and Schulze, 1995). The MUSLE is used in the estimation of sediment yield arising from a specific storm event (Hui-Ming and Yang, 2009). The event sediment yield, $Y_{\text {sd }}(\mathrm{t})$ is determined from stormflow volume for the event, $Q_{\mathrm{v}}\left(\mathrm{m}^{3}\right)$, event peak discharge, $q_{\mathrm{p}}\left(\mathrm{m}^{3} \cdot \mathrm{s}^{-1}\right)$, soil erodibility factor, $K\left(\mathrm{t} \cdot \mathrm{h} \cdot \mathrm{N}^{-1} \cdot \mathrm{ha}^{-1}\right)$, slope length factor, $L$, slope steepness factor, $S$, cover management factor, $C$, supporting practices factor, $P$, and location-specific MUSLE coefficients, $\alpha_{\text {sy }} \beta_{\text {sy }}$ as shown in Eq. 6 (Hui-Ming and Yang, 2009).

$$
Y_{\mathrm{sd}}=\alpha_{\mathrm{sy}}\left(Q_{\mathrm{v}} \cdot q_{\mathrm{p}}\right)^{\beta_{\mathrm{sy}}} K \cdot L \cdot S \cdot C \cdot P
$$

\section{DATA AND METHODS}

\section{Study area}

The study area is located at La Mercy, $28 \mathrm{~km}$ north of Durban, South Africa, on the site that now hosts the King Shaka International Airport. The research catchments were established 
by the South African Sugarcane Research Institute (SASRI), formerly South African Sugar Experiment Station (SASEX), and were monitored under bare cover and various sugarcane management practices. There were 4 small catchments numbered from south to north (Platford and Thomas, 1985), with Catchment 101 the southernmost catchment and Catchment 104 the northernmost catchment (Maher, 1990). However, it was impossible to maintain all four catchments completely and constantly under bare fallow conditions due to weeds, and the catchments were occasionally ploughed (Platford and Thomas, 1985). The layout of the catchments is shown in Fig. 1 and the catchment characteristics and soil types are summarised in Table 1 and Table 2, respectively.

\section{Data}

Daily observed rainfall and runoff depths, checked for errors with clarification of probable inconsistencies in observed data between catchments, and collated into the ACRU composite hydrometeorological data file format, were extracted from studies conducted by Smithers et al. (1996). Some records from major storms resulting from Cyclone Domoina in early 1984 and the September 1987 floods were lost due to equipment failure (Platford, 1988; Maher, 1990). Platford and Thomas (1985) and Maher (1990) further noted that sampling equipment were frequently washed away or completely silted up, thereby leading to a lack of records under bare fallow conditions, while Haywood

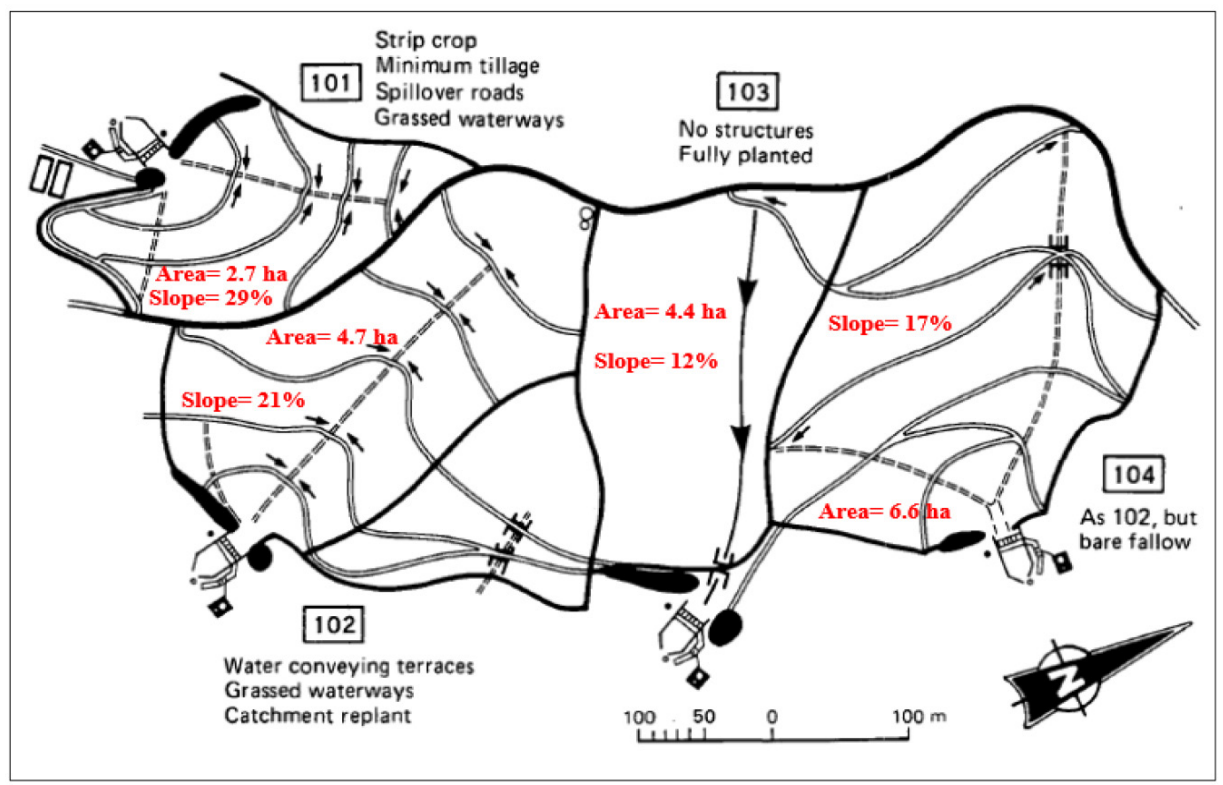

Figure 1. Layout of the La Mercy catchments, contour banks and waterways (after Platford and Thomas, 1985)

Table 1. Characteristics and management practices of the La Mercy catchments (after Platford and Thomas, 1985, Smithers et al., 1996)

\begin{tabular}{|c|c|c|c|c|}
\hline \multirow[t]{2}{*}{ Location/practice } & \multicolumn{4}{|c|}{ Catchment } \\
\hline & 101 & 102 & 103 & 104 \\
\hline Longitude & $31^{\circ} 07^{\prime} \mathrm{S}$ & $31^{\circ} 07^{\prime} \mathrm{S}$ & $31^{\circ} 07^{\prime} \mathrm{S}$ & $31^{\circ} 07^{\prime} \mathrm{S}$ \\
\hline Altitude/ elevation & 75 & 75 & 90 & 80 \\
\hline $\begin{array}{l}\text { Period of bare } \\
\text { fallow }\end{array}$ & $\begin{array}{l}\text { January } 1978 \text { to } \\
\text { August } 1984\end{array}$ & $\begin{array}{l}\text { January } 1978 \text { to } \\
\text { August } 1984\end{array}$ & January 1978 to August 1984 & January 1978 to December 1985 \\
\hline $\begin{array}{l}\text { Period of sugarcane } \\
\text { cover conditions }\end{array}$ & $\begin{array}{l}\text { September } 1984 \text { to } \\
\text { December } 1995\end{array}$ & $\begin{array}{l}\text { September } 1984 \text { to } \\
\text { December } 1995\end{array}$ & $\begin{array}{c}\text { September } 1984 \text { to December } \\
1995\end{array}$ & January 1986 to December 1995 \\
\hline $\begin{array}{l}\text { Method of land } \\
\text { preparation }\end{array}$ & Minimum tillage ${ }^{1}$ & Conventional tillage $^{2}$ & Conventional tillage $^{2}$ & Conventional tillage ${ }^{2}$ \\
\hline Grass waterways & Yes & Yes & $\begin{array}{c}\text { No, but had natural depression } \\
\text { sown with Eragrostis curvula } \\
\text { before planting }\end{array}$ & Yes \\
\hline
\end{tabular}

'Minimum tillage is the practice of reduced soil disturbance when the land is being prepared for planting (SASRI, 1998).

${ }^{2}$ Conventional tillage is the standard practice of ploughing with a disc, single or various disc harrows, a spike-tooth harrowing and surface planting (Morgan, 2005).

Table 2. Soil type distributions in the La Mercy catchments (after Platford and Thomas, 1985, Smithers et al., 1996)

\begin{tabular}{|c|c|c|c|c|c|c|c|}
\hline \multirow[t]{2}{*}{ Soil form* } & \multirow[t]{2}{*}{ Soil series* } & \multirow[t]{2}{*}{ Soil code* } & \multirow[t]{2}{*}{ Soil depth (m) } & \multicolumn{4}{|c|}{ Area per catchment (\%) } \\
\hline & & & & 101 & 102 & 103 & 104 \\
\hline Hutton & Clansthal & $\mathrm{Hu} 24$ & $>1.0$ & 0 & 0 & 0 & 10 \\
\hline Arcadia & Rydalvale & Ar30 & $0.3-0.9$ & 71 & 97 & 98 & 37 \\
\hline Swartland & Swartland & Sw31 & $0.1-0.6$ & 29 & 3 & 2 & 53 \\
\hline
\end{tabular}

*MacVicar et al. (1977) 
(1991) noted that measuring equipment were poorly calibrated. Furthermore, storms which occurred after harvesting would cause residue to block the entrance of measuring flumes, hence resulting in reduced flows captured by the collecting tanks. Theft and vandalism of the intensity gauges was also a big problem and a number of records from the automatic recorders were affected (Maher, 1990). In addition, various sediment yield records were incomplete and Maher (1990) only analysed 4 events of complete sediment yield records.

The available data comprises of daily observed rainfall and runoff for the period 1978-1995, peak discharge for the period 1984-1995 and daily maximum and minimum temperature and A-pan data for the period 1978-1995. Historical information on the management practices at the La Mercy catchments for the period 1978-1988 was also obtained from studies reported by Haywood (1991).

\section{Model verification and performance}

Smithers et al. (1996) used Eqs 1, 3 and 6 embedded in the ACRU model to simulate stormflow, peak discharge and sediment yield, respectively, from the La Mercy catchments under bare fallow conditions and sugarcane production. The ACRU model was found to be generally suitable in the investigation of the effect of sugarcane production on water resources, despite some inadequacies in the simulation of stormflow, peak discharge and sediment yield. As part of the verification undertaken in this study, daily rainfall was further quality controlled and used as input into the ACRU model to simulate stormflow, peak discharge and sediment yield and the results compared against respective observed events that were considered to be reliable. Inconsistencies in the records that were excluded from verifications included events with:

(i) runoff volumes equal to zero but with rainfall greater than or equal to $25 \mathrm{~mm}$

(ii) rainfall depth equal to zero but runoff volume greater than zero

(iii) peak discharge values for which either rainfall depth or runoff volume was missing

(iv) sediment yield records for which no runoff volume was available

The inconsistent events are listed in Otim (2018) while the methodology used in refining model verification is presented in the subsequent sections.

\section{Simulation and verification of daily runoff volume}

The ACRU variables used in the simulation of runoff volume from the La Mercy catchments were obtained from Smithers et al. (1996) and the Sugarcane Decision Support System (SCDSS) documented in the same report. The relevant ACRU variables are shown in Table 3 and runoff simulated using Eq. 1. The performance of the ACRU model was then assessed by comparing the simulated runoff depth to the observed runoff depth.

Table 3. Soil variable and parameter selections (after Smithers et al., 1996)

\begin{tabular}{|c|c|c|c|c|}
\hline Variable/ parameter & Catchment 101 & Catchment 102 & Catchment 103 & Catchment 104 \\
\hline DEPAHO & 0.30 & 0.30 & 0.30 & 0.30 \\
\hline DEPBHO & 0.43 & 0.49 & 0.49 & 0.49 \\
\hline WP1 & 0.228 & 0.248 & 0.248 & 0.192 \\
\hline WP2 & 0.239 & 0.244 & 0.245 & 0.220 \\
\hline FC1 & 0.344 & 0.367 & 0.368 & 0.304 \\
\hline FC2 & 0.370 & 0.375 & 0.376 & 0.347 \\
\hline PO1 (BF) & 0.523 & 0.534 & 0.534 & 0.522 \\
\hline P01 (SP) & 0.505 & 0.523 & 0.523 & 0.493 \\
\hline PO2 & 0.455 & 0.475 & 0.475 & 0.433 \\
\hline ABRESP (BF) & 0.70 & 0.70 & 0.70 & 0.70 \\
\hline ABRESP (SP) & 0.25 & 0.25 & 0.25 & 0.22 \\
\hline BFRESP & 0.21 & 0.25 & 0.25 & 0.22 \\
\hline COIAM (BF) & 0.35 & 0.35 & 0.35 & 0.35 \\
\hline COIAM (SP) & 0.40 & 0.25 & 0.20 & 0.25 \\
\hline SMDDEP (BF) & 0.25 & 0.30 & 0.30 & 0.30 \\
\hline SMDDEP (SP) & 0.35 & 0.35 & 0.35 & 0.35 \\
\hline COFRU & 0.02 & 0.02 & 0.02 & 0.02 \\
\hline QFRESP & 1.00 & 1.00 & 1.00 & 1.00 \\
\hline
\end{tabular}

\section{(BF)}

$(S P)$

DEPAHO, DEPBHO

WP1, WP2

$F C 1, F C 2$

$P O 1, P O 2$

ABRESP

BFRESP

COIAM

SMDDEP

COFRU

QFRESP
Bare fallow value of the variable/parameter

Value of the variable/parameter during sugarcane production

Thicknesses of top-and subsoil respectively $(m)$

Permanent wilting points of top-and subsoil respectively $\left(\mathrm{m} \cdot \mathrm{m}^{-1}\right)$

Drained upper limits of top-and subsoil respectively $\left(\mathrm{m} \cdot \mathrm{m}^{-1}\right)$

Porosities of top-and subsoil horizons respectively $\left(\mathrm{m} \cdot \mathrm{m}^{-1}\right)$

Saturated redistribution fraction from topsoil to subsoil

Saturated redistribution fraction from subsoil horizon to intermediate/groundwater store

Coefficient of initial abstraction

Effective depth of soil for stormflow response $(m)$

Coefficient of base flow response

Catchment stormflow response fraction 


\section{Simulation and verification of daily peak discharge}

In this study, Type 2 rainfall intensity distribution (Schulze et al., 2004) was used and simulation of daily peak discharge was conducted using the SCS triangular-shaped incremental unit hydrograph approach shown in Eq. 3. The lag time was estimated using the Schmidt-Schulze lag equation shown in Eq 4 and these lag times were converted into time of concentration $\left(T_{c}\right)$, as shown in Table $4 . T_{c}$ calculated from lag estimated by the hydraulic principles and the SCS method (Schulze and Schmidt, 1995) are included for comparative purposes. Simulated runoff volume obtained using Eq. 1 was used as input to simulate peak discharge. The simulated peak discharge values were then verified through comparisons with observed peak discharges.

\section{Simulation and verification of daily sediment yield}

Simulation of daily sediment yield was driven by the simulated stormflow volumes and simulated peak discharges using Eq. 6 embedded in the ACRU model. The various MUSLE parameters (i.e. $K, L, S$ and $P$ ) representing conditions and practices at the La Mercy catchments were estimated wherever possible using an appropriate level of data requirement, as outlined by Lorentz and Schulze (1995), while the dynamic $C$ factors were obtained from Smithers et al. (1996). The $K$ factor was estimated using the Level 1 input option which determines the soil erodibility class from the binomial classification of the soil, the LS factor was also estimated using the Level 1 input option (limited information on catchment available) which relates the LS factor to the slope gradient, and the $P$ factor was estimated using the Level 3 input option which takes into account contouring, strip cropping, terracing and subsurface drainage. The $C$ factors were taken from studies conducted by Smithers et al. (1996) with the assumption that the $C$ factor for sugarcane at full canopy was 0.01 and after harvesting was 0.60 , and that full canopy is achievable in 5 months for cane harvested in the summer months and 6 months for cane harvested during winter. The $K$ factors were area-weighted according to soil properties and area covered, $C$ factors were dynamically varied according to the stage of growth and harvesting practice, and constant LS and $P$ factors were employed since they do not vary. The parameters used in the simulation of sediment yield are shown in Table 5 while the dynamically varying cover factors $(C)$ for sugarcane are shown in Table 6.

\section{RESULTS AND DISCUSSION}

In this section, the results of simulations and verification of runoff, peak discharge and sediment yield for the La Mercy catchments are presented and discussed.

\section{Verification of runoff volume}

A discussion of runoff verification under both bare fallow and sugarcane cover conditions is presented below. The parameters used in the verification were obtained as outlined above.

Table 4. Estimated time of concentration

\begin{tabular}{|c|c|c|c|}
\hline Catchment & $\begin{array}{l}\text { Time of concentration } \\
\text { using Schmidt-Schulze lag equation }(h) \\
\text { (Schmidt and Schulze, 1984) }\end{array}$ & $\begin{array}{l}\text { Time of concentration } \\
\text { using hydraulic principles }(h) \\
\text { (Schulze and Schmidt, 1995) }\end{array}$ & $\begin{array}{l}\text { Time of concentration } \\
\text { using SCS method }(h) \\
\text { (Schulze and Schmidt, 1995) }\end{array}$ \\
\hline 101 & 0.94 & 1.91 & 1.01 \\
\hline 102 & 1.26 & 2.20 & 1.58 \\
\hline 103 & 1.45 & 1.64 & 1.73 \\
\hline 104 & 1.51 & 2.50 & 1.63 \\
\hline
\end{tabular}

Table 5. MUSLE parameters used for the simulation of sediment yield

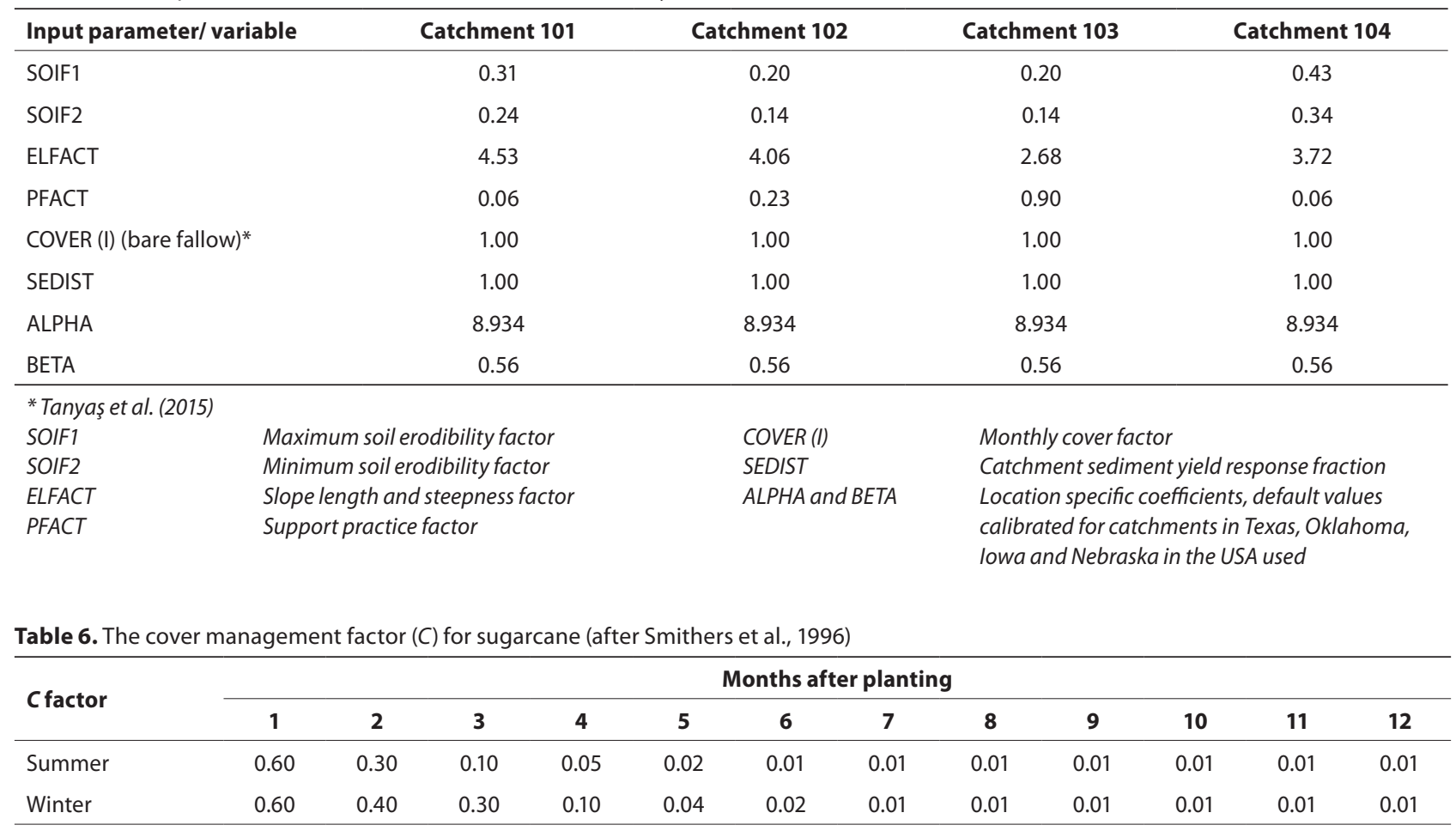




\section{Bare fallow conditions}

A discussion of runoff verification results under bare fallow conditions for each of the La Mercy catchments is presented below.

\section{Catchment 101}

Daily values under bare fallow conditions from Catchment 101 are presented in Fig. 2 while the simulated vs observed, and frequency distribution plots, are shown in Figs $3 a$ and $3 b$, respectively. The linear regression statistics and the NSE which indicate how well the daily stormflow depth was simulated are shown in Fig. 3a.

As shown in Fig. 2, simulation of runoff from Catchment 101 under bare fallow conditions resulted in an overall undersimulation of $5.5 \%$ over the period simulated, which is generally good. In addition, the scatter around the 1:1 line was relatively good, with runoff generally under-simulated as indicated in Figs $3 \mathrm{a}$ and $3 \mathrm{~b}$, respectively. It is hypothesised that the general under-simulation of runoff could be due to a random error in the measurement of large runoff volumes.

\section{Catchment 102}

Catchment 102 daily values under bare fallow conditions are shown in Fig. 4, while the simulated vs observed plots with the regression statistics and frequency distribution plots are shown in Figs 5a and 5b, respectively.

For Catchment 102 under bare fallow conditions, runoff simulation was generally good and resulted in an overall undersimulation of $1.6 \%$ as shown in Fig. 4. Additionally, the runoff relative sequences and orders of magnitude were reasonably simulated, as shown in the same figure, and the simulations were acceptable as shown by the regression statistics and the NSE in Fig. 5a; large runoff volumes were generally over-simulated while small runoff volumes were under-simulated as shown in Fig. 5b. The over- and under-simulations could be attributed to random errors in the measurement of daily runoff volumes.

\section{Catchment 103}

The daily values for Catchment 103 under bare fallow conditions are shown in Fig. 6, while the linear regression plots with the statistics and the frequency distribution plots are shown in Figs $7 \mathrm{a}$ and $7 \mathrm{~b}$, respectively.

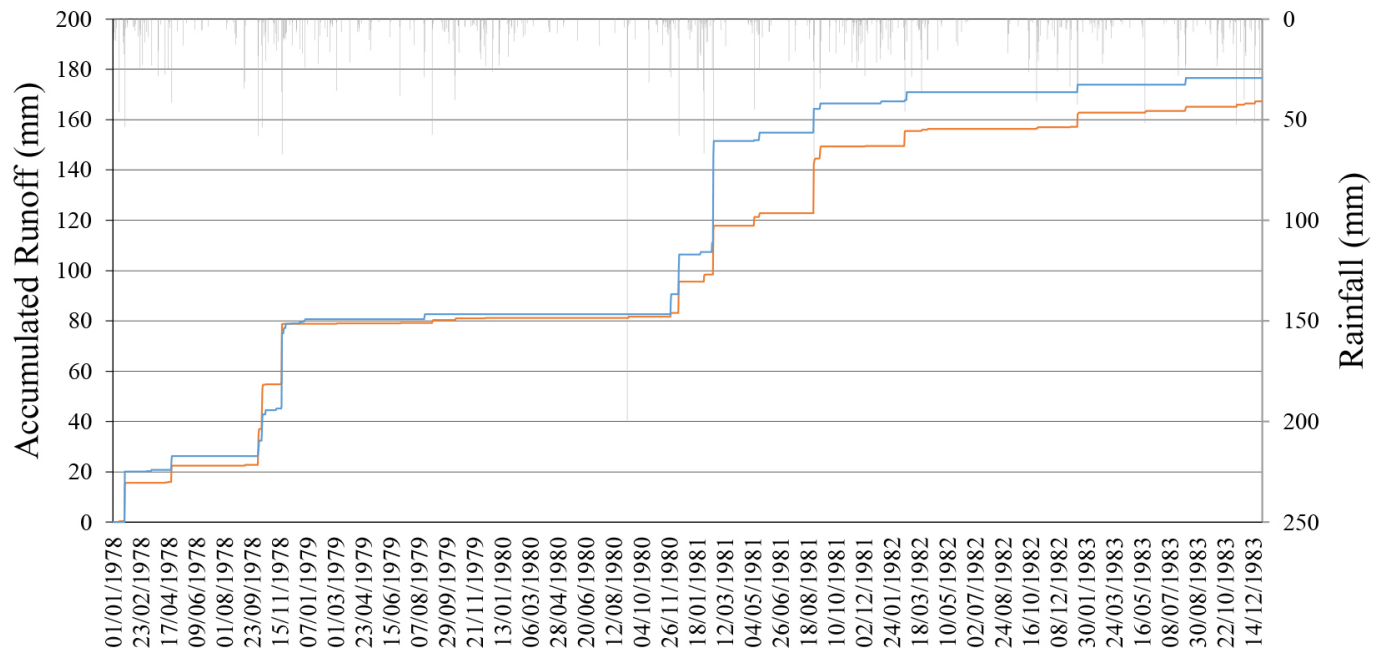

Date

Rainfall —_ Simulated Runoff —observed Runoff

Figure 2. Daily rainfall and runoff simulated with the SCDSS: Catchment 101, bare fallow conditions

(a)

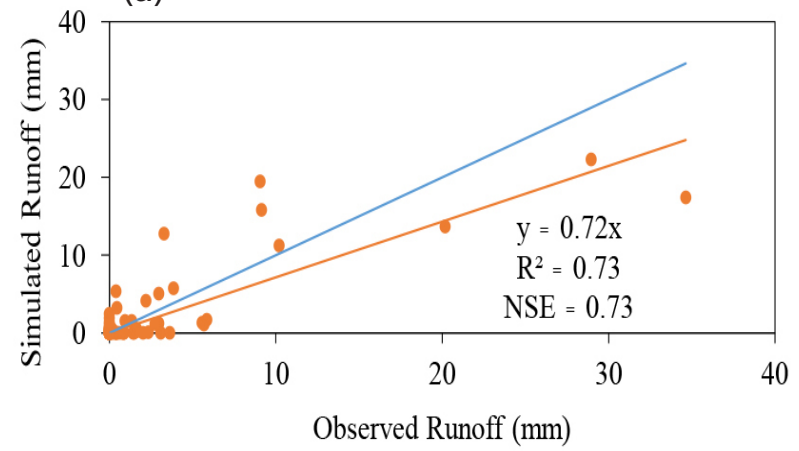

- Simulated $\quad-$ Linear (1:1 line) - Linear (Simulated) (b)

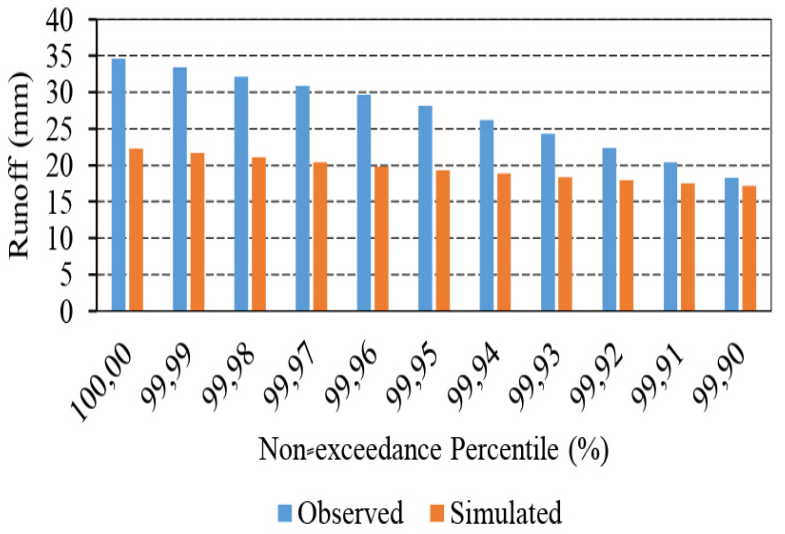

Figure 3. (a) Simulated vs observed and (b) frequency distribution plots: Daily runoff volumes simulated from Catchment 101 under bare fallow cover 


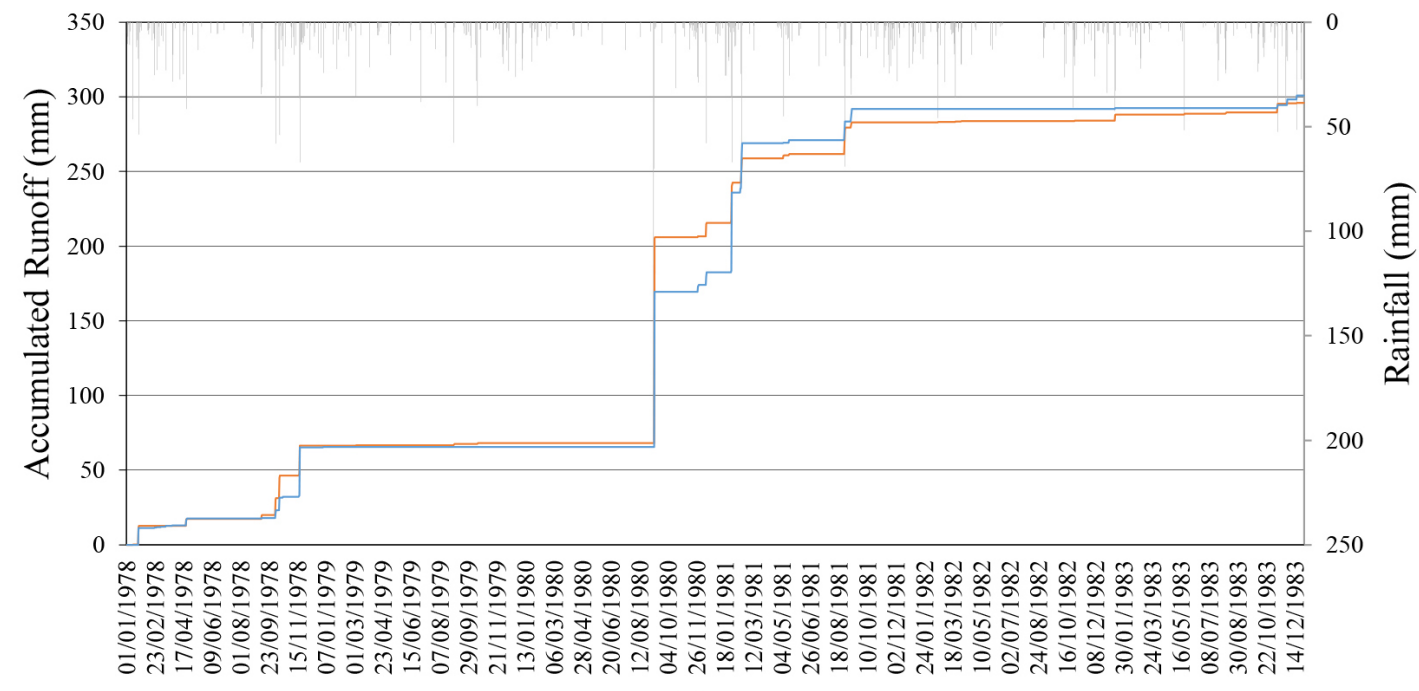

Date

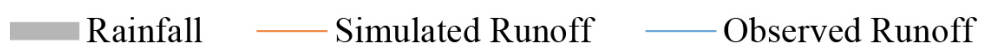

Figure 4. Daily rainfall and runoff simulated with the SCDSS: Catchment 102, bare fallow conditions

(a)

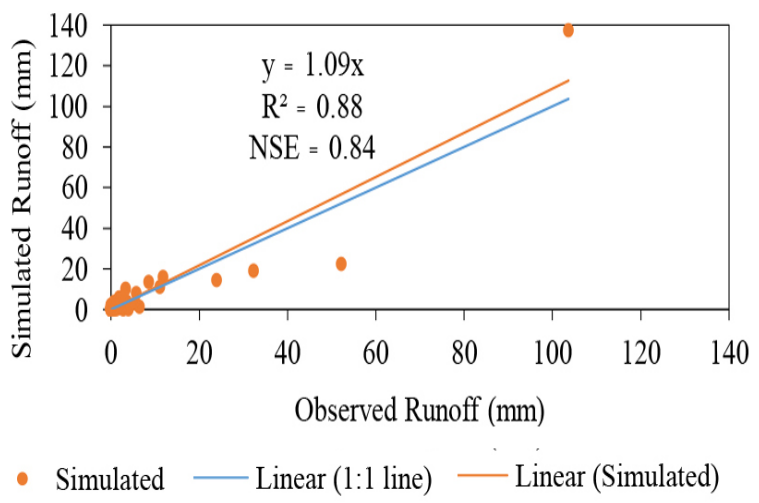

(b)

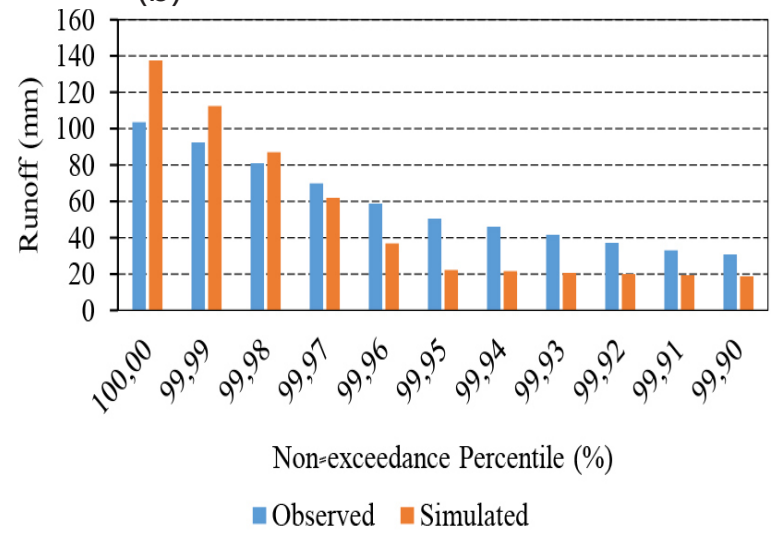

Figure 5. (a) Simulated vs observed and (b) frequency distribution plots: Daily runoff volumes simulated from Catchment 102 under bare fallow cover

From Fig. 6, it is evident that the simulation resulted in an overall under-simulation of $7.8 \%$, which was good. Furthermore, an acceptable model fit between observed and simulated daily runoff exists, as shown by the regression statistics in Fig. 7a, and the large daily runoff volumes were over-simulated while the small runoff volumes were under-simulated as shown in Fig. 7b. Similar to Catchment 102, the over- and under-simulations could be attributed to random errors in the measurement of daily runoff volumes.

\section{Catchment 104}

The daily values for Catchment 104 under bare fallow conditions are shown in Fig. 8, while the simulated vs observed plots, together with the regression statistics and frequency distribution plots, are shown in Figs 9a and 9b, respectively.

As shown in Fig. 8, runoff simulation resulted in a consistent under-simulation, and the scatter around the 1:1 line was fairly good as shown by the regression statistics in Fig. 9a; runoff volume was consistently under-simulated as shown in Fig. 9b. It was initially suspected that the consistent under-simulation could be attributed to the soil variables and parameter selections shown in Table 3, but a scrutiny of the parameters showed they were justifiably selected. Further comparisons between observed and simulated runoff volumes showed that runoff was generally under-simulated by $40 \%$. Hence, it is suspected that the general under-simulation of runoff could be due to a systematic error in the measurement of runoff volumes, caused by poor calibration of measuring equipment as documented by Haywood (1991). Scaling the observed runoff by a factor of $40 \%$ greatly improved the verifications, as shown in Fig. 10.

\section{Sugarcane cover conditions}

The discussion of runoff verification results under sugarcane cover conditions for each of the La Mercy catchments is presented below.

\section{Catchment 101}

Catchment 101 daily values under sugarcane land cover are shown in Fig. 11, while the linear regression plots with the statistics and the frequency distribution plots are shown in Figs $12 \mathrm{a}$ and $12 \mathrm{~b}$, respectively. 


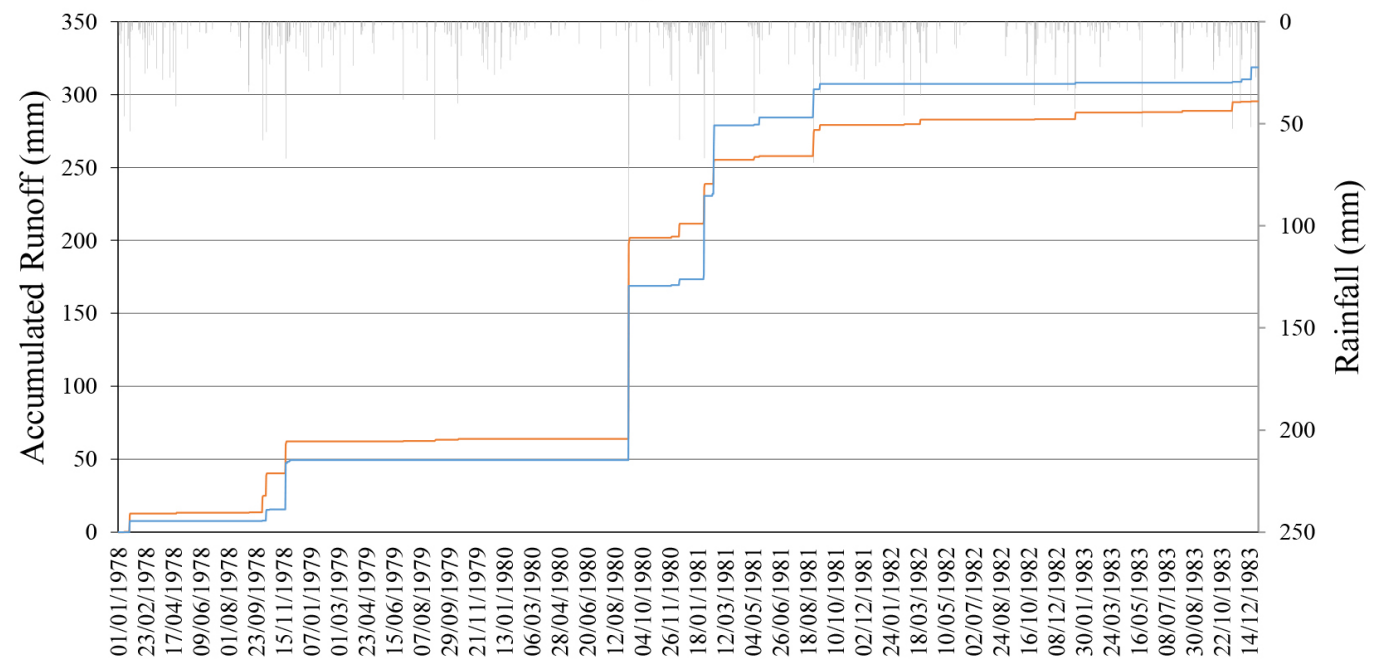

Date

Rainfall — Simulated Runoff —observed Runoff

Figure 6. Daily rainfall and runoff simulated with the SCDSS: Catchment 103, bare fallow conditions

(a)

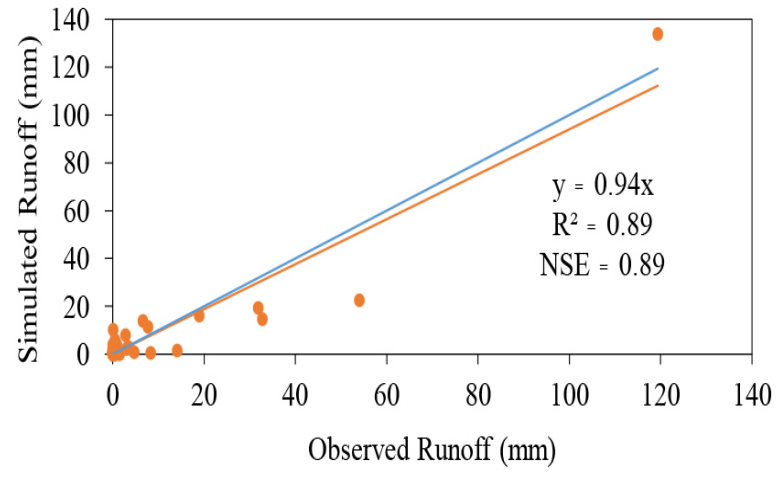

- Simulated L Linear (1:1 line) — Linear (Simulated) (b)

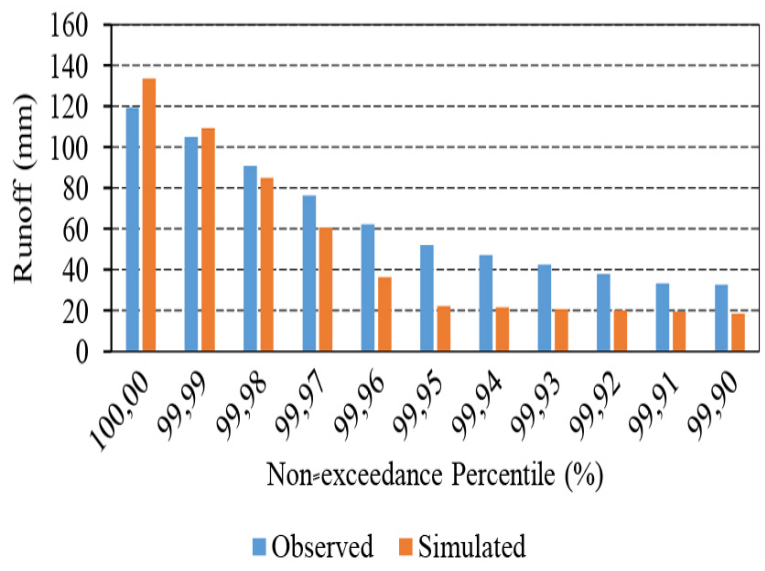

Figure 7. (a) Simulated vs observed and (b) frequency distribution plots: Daily runoff volumes simulated from Catchment 103 under bare fallow cover

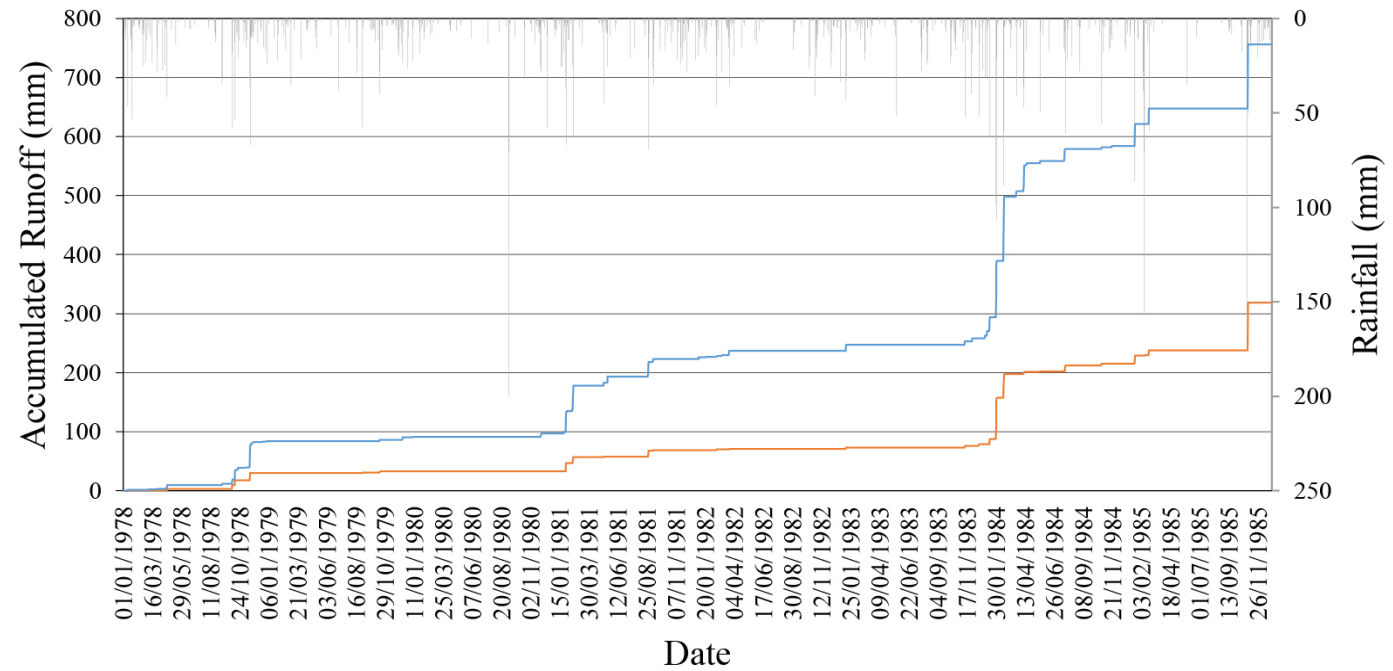

Rainfall $\quad$ Simulated Runoff —observed Runoff

Figure 8. Daily rainfall and runoff simulated with the SCDSS: Catchment 104, bare fallow conditions 
(a)

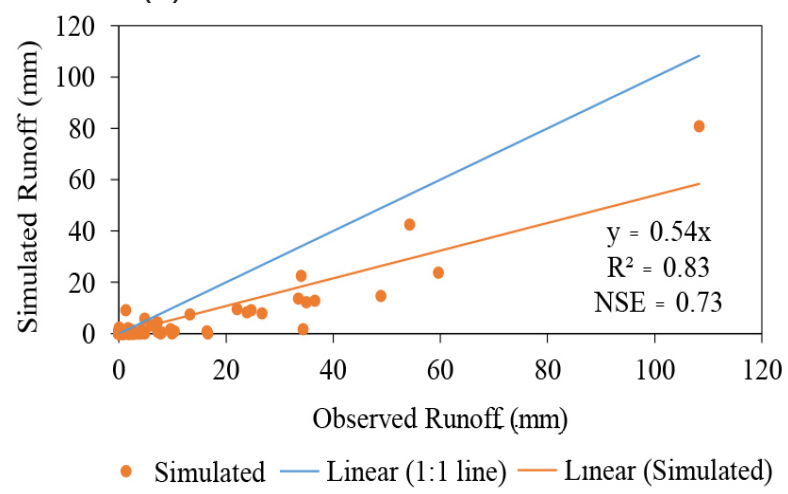

(b)

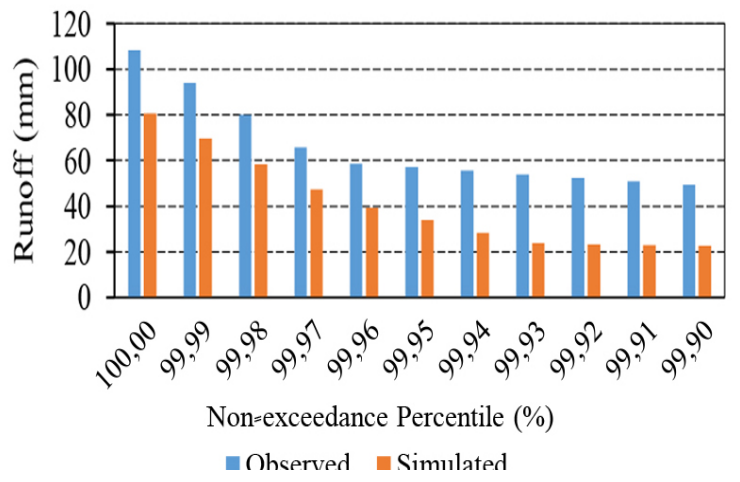

Figure 9. (a) Simulated vs observed and (b) frequency distribution plots: Daily runoff volumes simulated from Catchment 104 under bare fallow cover

Generally, runoff simulated from Catchment 101 resulted in an over-simulation for the period as shown in Fig. 11 and represents an overall over-simulation of $14.5 \%$. The association between observed and simulated runoff was acceptable, as indicated by the regression statistics and the NSE in Fig. 12a, and runoff was consistently over-simulated as shown by the frequency plots in

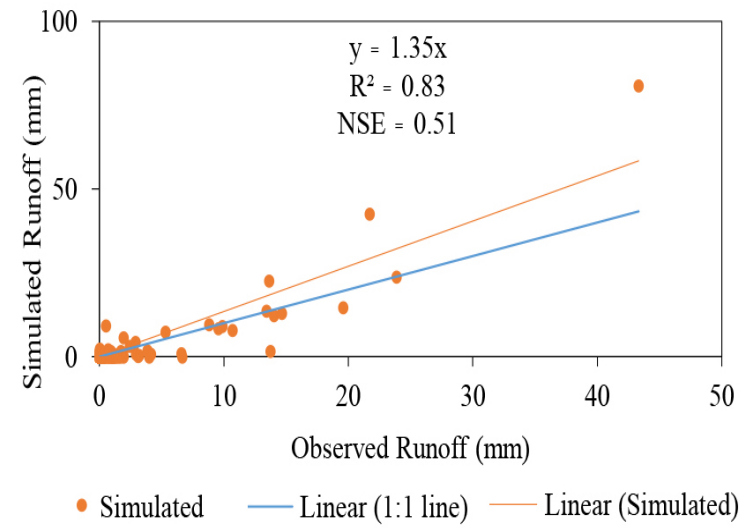

Figure 10. Daily runoff volumes simulated from Catchment 104 under bare fallow cover with observed runoff scaled by a factor of $40 \%$
Fig. 12b. The general over-simulation of runoff volume could be attributed to random errors in the measurement of daily runoff volumes.

\section{Catchment 102}

Catchment 102 daily values under sugarcane land cover are shown in Fig. 13 while the linear regression plots together with the statistics and frequency distribution plots are shown in Figs 14a and 14b, respectively.Simulation of daily runoff generally resulted in a close relationship between observed and simulated runoff, as shown in Fig. 13, and gave rise to an overall under-simulation of $13.1 \%$. The general scatter of the simulated runoff around the 1:1 line is also acceptable as indicated by the regression statistics and the NSE in Fig. 14a, with some underand over-simulations as shown in Fig. 14b. The under- and oversimulation of runoff volumes could be attributed to similar reasons to those cited under Catchment 101.

\section{Catchment 103}

Catchment 103 daily values under sugarcane land cover are shown in Fig. 15, while the linear regression plots and statistics and frequency distribution plots are shown in Figs 16a and 16b, respectively.

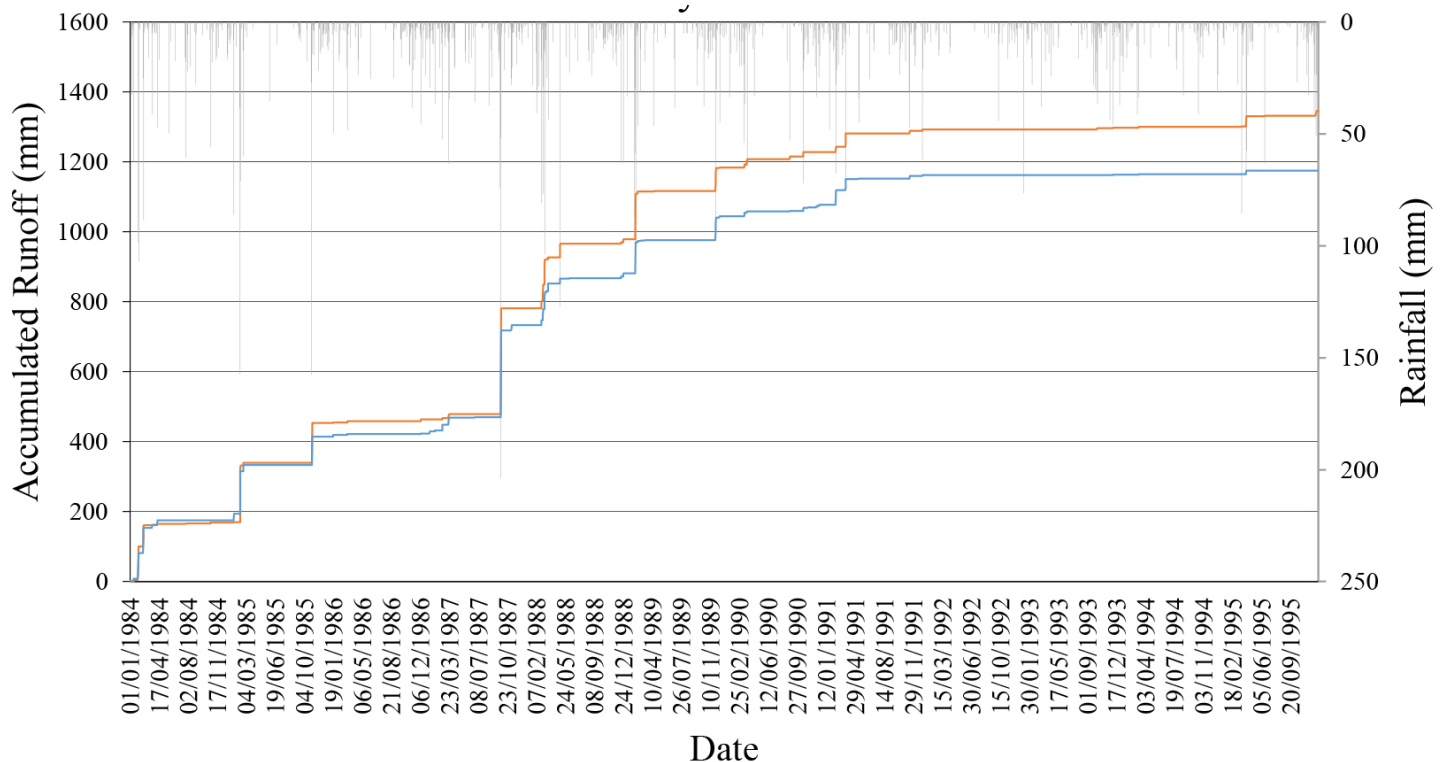

Rainfall —- Simulated Runoff $\quad$ Observed Runoff

Figure 11. Daily rainfall and runoff simulated with the SCDSS: Catchment 101, sugarcane cover conditions 
(a)

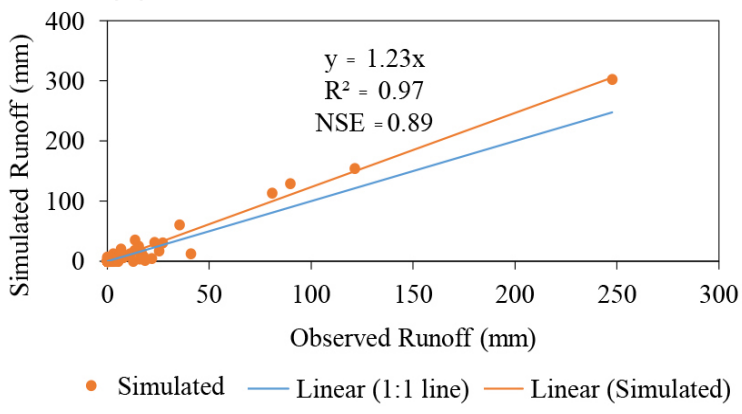

(b)

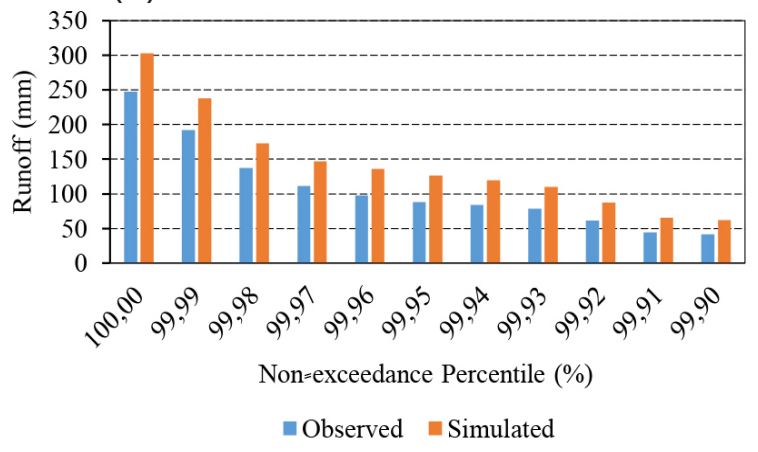

Figure 12. (a) Simulated vs observed and (b) frequency distribution plots: Daily runoff volumes simulated from Catchment 101 under sugarcane cover

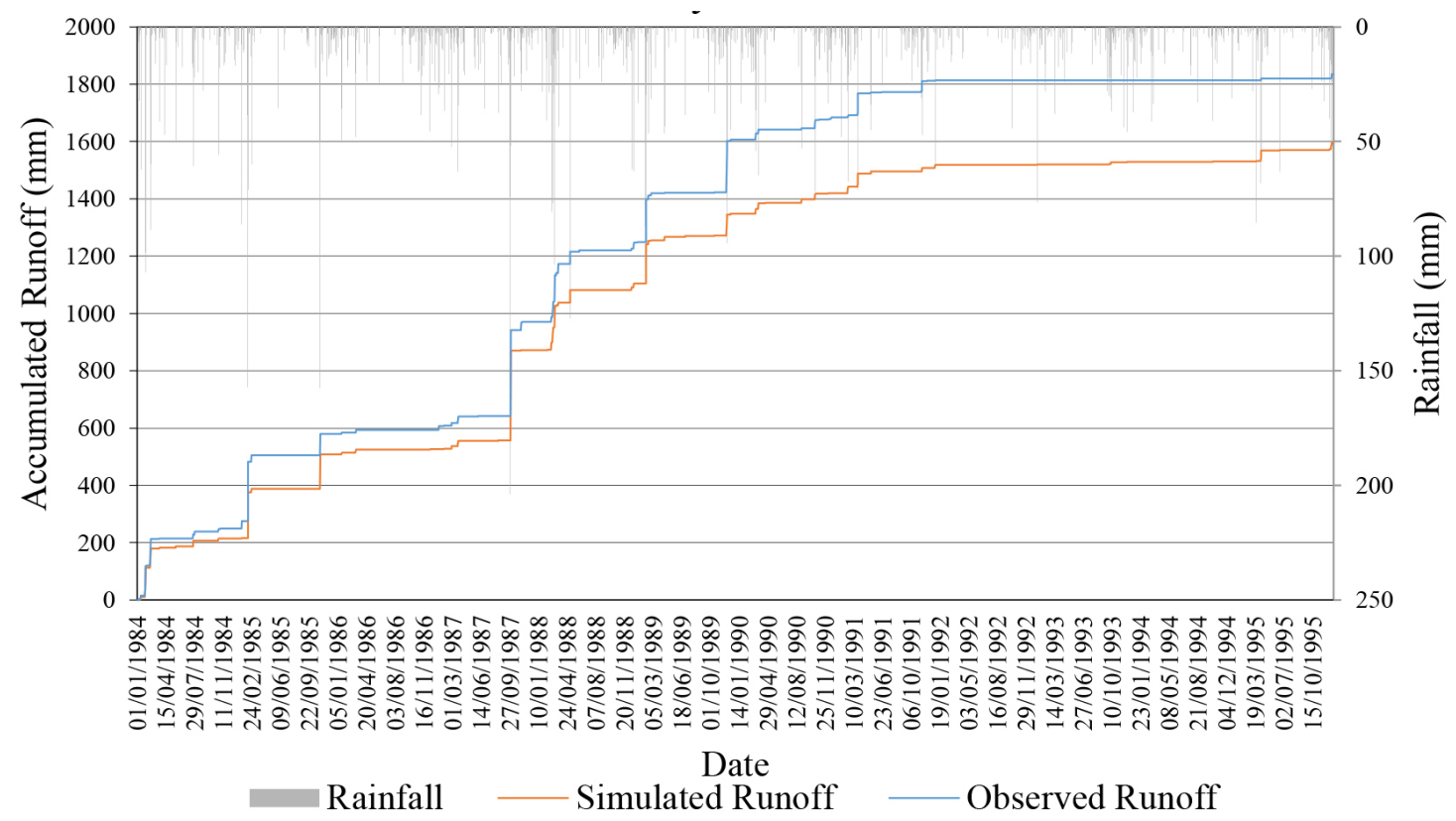

Figure 13. Daily rainfall and runoff simulated with the SCDSS: Catchment 102, sugarcane cover conditions

(a)

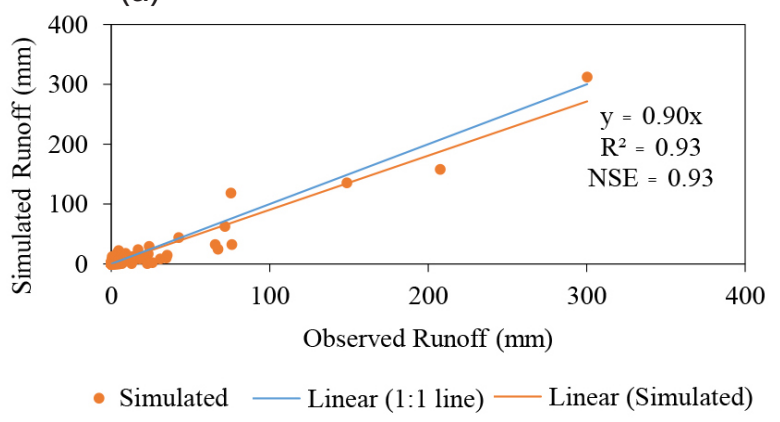

(b)

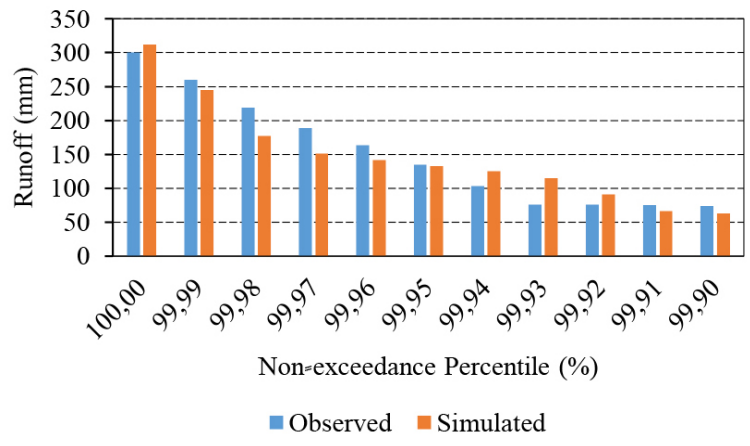

Figure 14. (a) Simulated vs observed and (b) frequency distribution plots: Daily runoff volumes simulated from Catchment 102 under sugarcane cover

Runoff simulation generally gave rise to an over-simulation for the period as shown in Fig. 15, with an overall over-simulation of $0.5 \%$. In addition, the general plot around the $1: 1$ line is acceptable, as indicated by the regression statistics and the NSE in Fig. 16a, and the frequency distribution closely related as shown in Fig. 16b. However, both under- and over-simulations exist and this could be attributed to the same reasons discussed under Catchment 101.

\section{Catchment 104}

Catchment 104 daily values under sugarcane land cover are shown in Fig. 17, while the linear regression plots and statistics and frequency distribution plots are shown in Figs 18a and 18b, respectively.Use of the SCDSS parameters to simulate runoff resulted in a consistent under-simulation, with an overall under-simulation of $40.8 \%$ as shown in Fig. 17. However, the general plot around the 1:1 line was reasonably good, as shown by the regression statistics and the NSE in Fig. 18a and runoff was consistently under-simulated as shown in Fig. 18b. The 


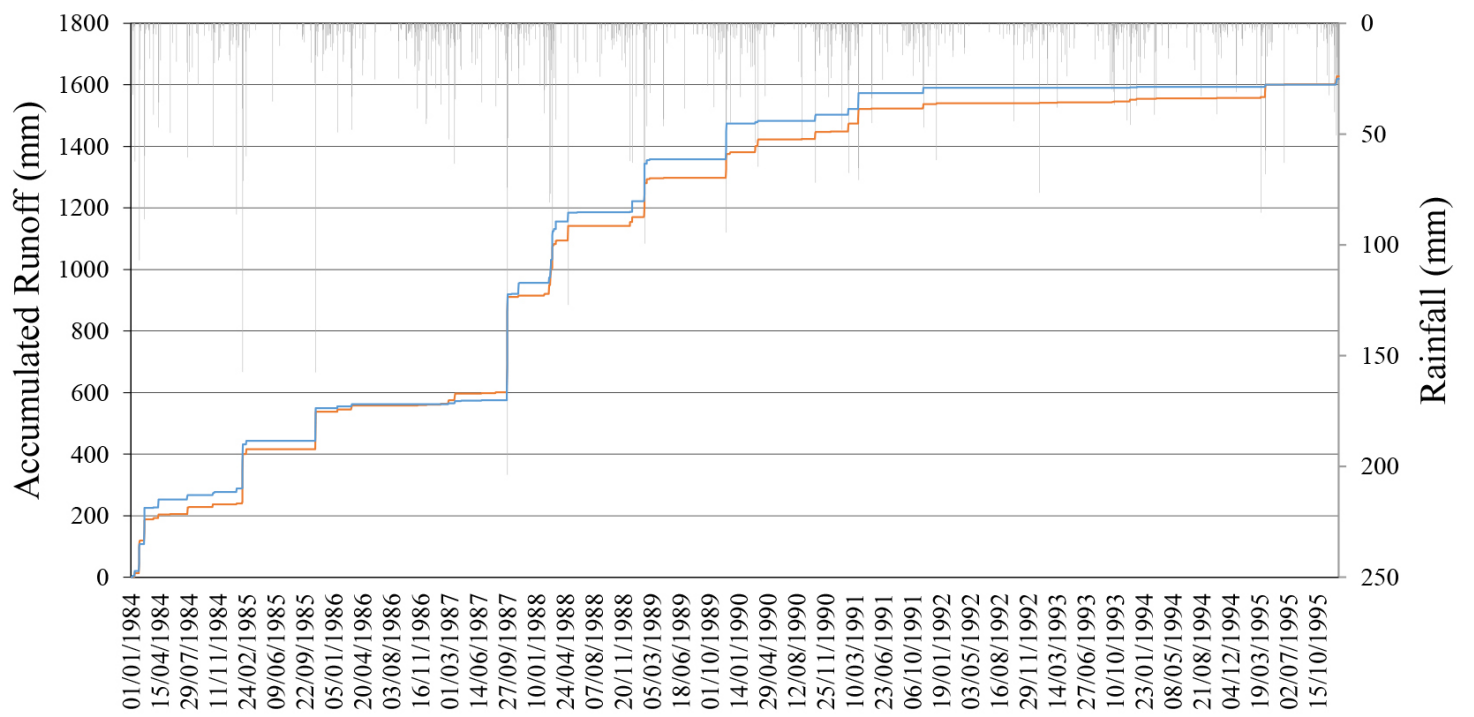

Date

Rainfall — Simulated Runoff $\quad$ Observed Runoff

Figure 15. Daily rainfall and runoff simulated with the SCDSS: Catchment 103, sugarcane cover conditions

(a)

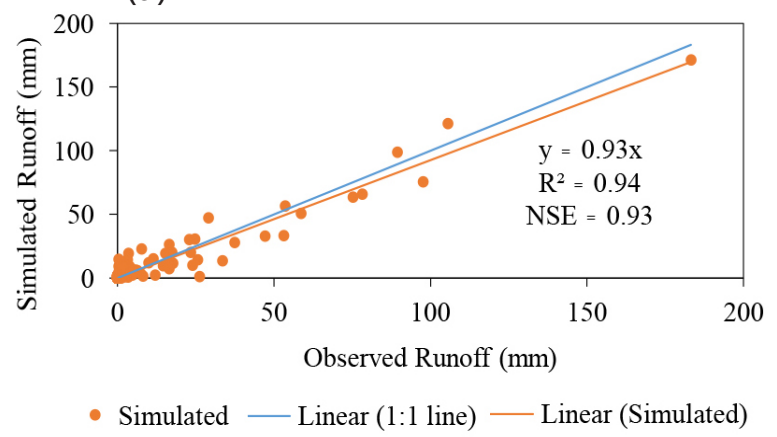

(b)

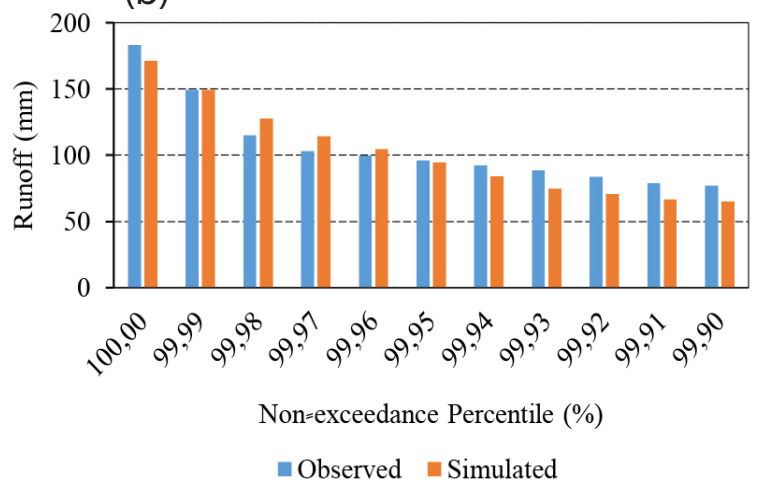

Figure 16. (a) Simulated vs observed and (b) frequency distribution plots: Daily runoff volumes simulated from Catchment 103 under sugarcane cover

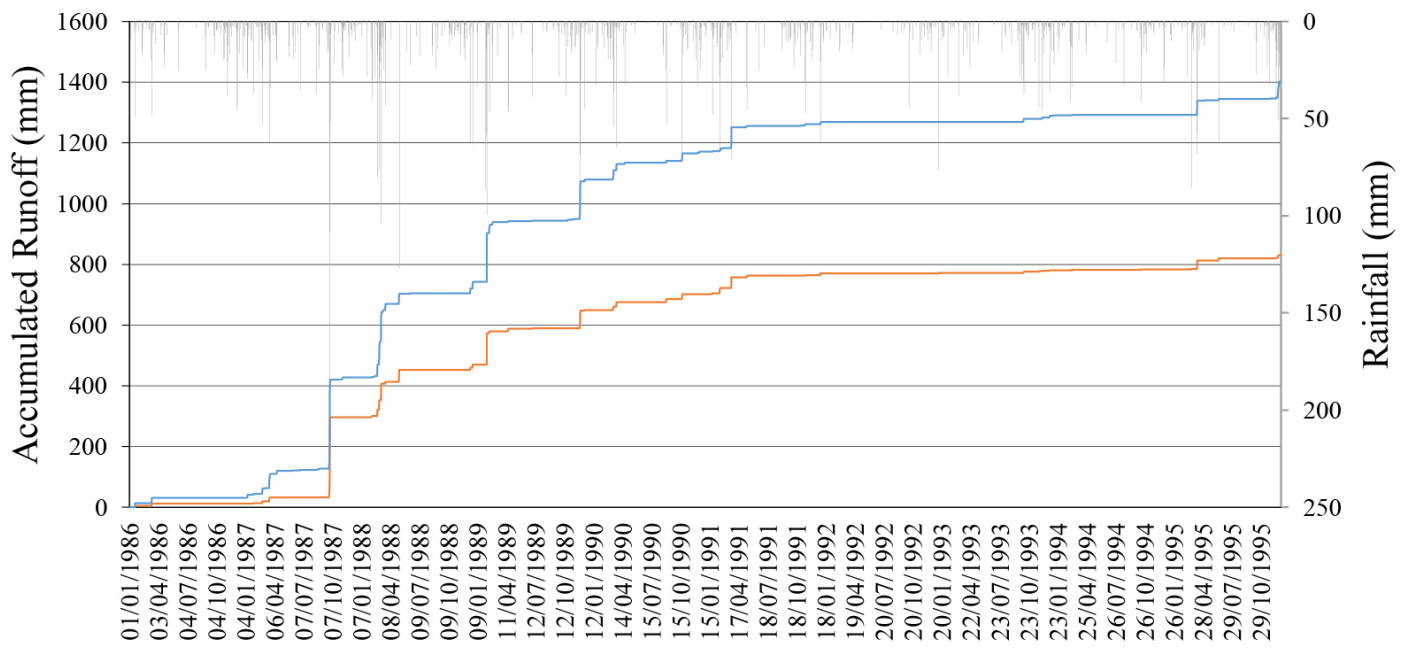

Date

Rainfall $\longrightarrow$ Simulated Runoff $\longrightarrow$ Observed Runoff

Figure 17. Daily rainfall and runoff simulated with the SCDSS: Catchment 104, sugarcane cover conditions 
(a)

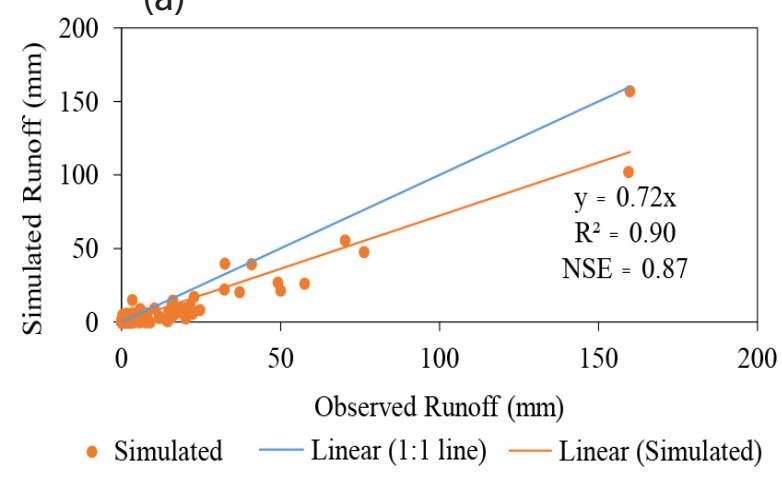

(b)

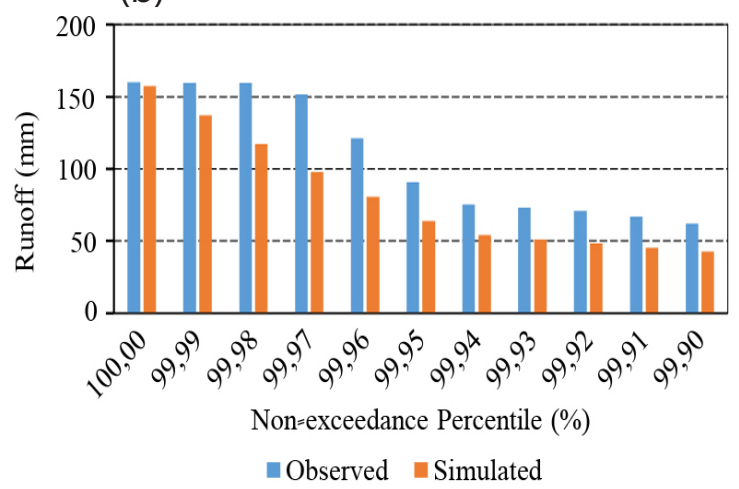

Figure 18. (a) Simulated vs observed and (b) frequency distribution plots: Daily runoff volumes simulated from Catchment 104 under sugarcane cover

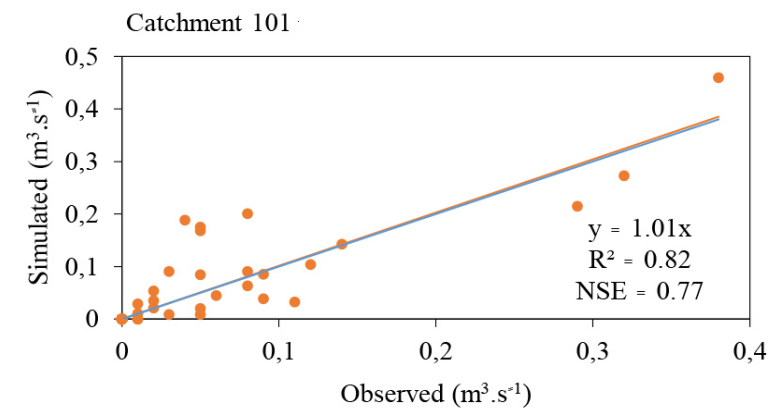

- Simulated — Linear (1:1 line) — Linear (Simulated)

Catchment 103

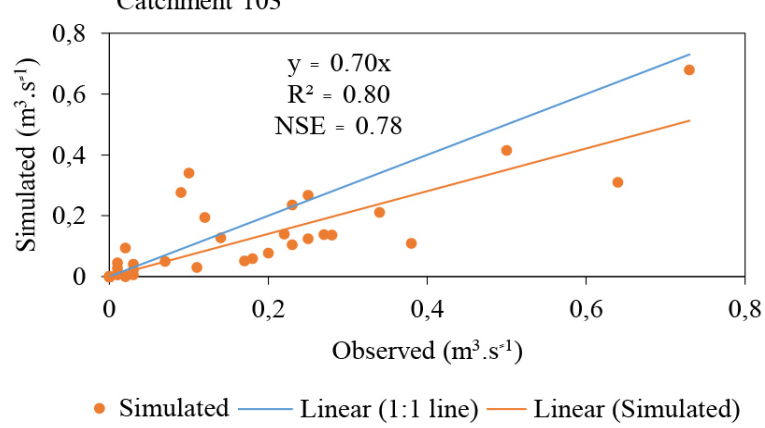

Catchment 102

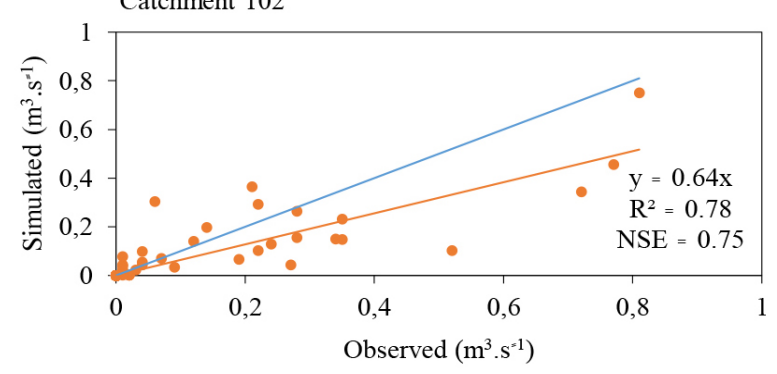

- Simulated — Linear (1:1 line) — Linear (Simulated)

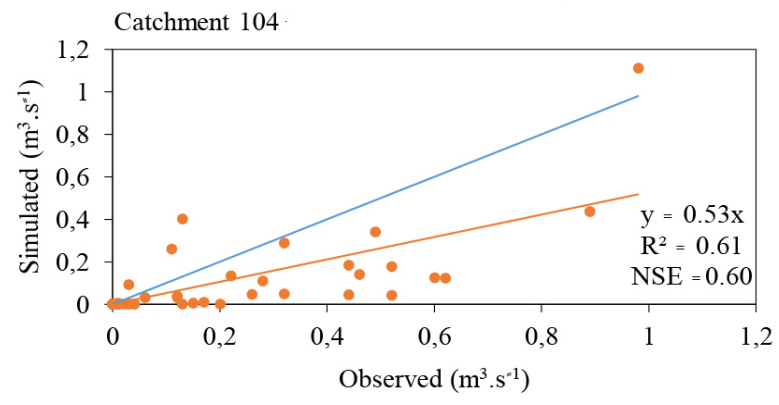

- Simulated L Linear (1:1 line) — Linear (Simulated)

Figure 19. Daily peak discharge simulated using observed daily rainfall, simulated stormflow volumes and estimated catchment times of concentration with the Schmidt-Schulze lag equation

consistent under-simulation could be attributed to random errors in the measurement of daily runoff volumes.

\section{Verification of daily peak discharge}

Verification of daily peak discharge was only conducted under sugarcane land cover since there was no observed peak discharge data available under bare fallow conditions. The results are summarised and presented in Fig. 19. The trends exhibited by simulated peak discharges shown in Fig. 19 are related to trends exhibited by simulated runoff volumes under each catchment and this confirms that runoff volume is a driver of peak discharge. Furthermore, the association between observed and simulated peak discharge across all four catchments is reasonably good, as indicated by the regression statistics and the NSE in Fig. 19 , and the trends in frequency distribution of simulated and observed peak discharge are also closely associated as shown in Fig. 20. Similar to runoff volume trends, the under- and oversimulations of peak discharge could be attributed to random errors in the measurement of daily peak discharge values.

\section{Verification of daily sediment yield}

Similar to daily peak discharge, daily sediment yield was verified under sugarcane land cover conditions since there were no observed sediment yield data available under bare fallow conditions. Considering that many sediment yield records were incomplete, only events documented by Maher (1990), together with a few consistent events, were used in the verifications. The results are presented in Fig. 21 and the discussions follow thereafter. The correlation between simulated and observed sediment yield events was reasonably good, as shown by the regression statistics and the NSE in Fig. 21; the events used in the verication are shown in Table 7.

\section{CONCLUSIONS}

Generally, the relative sequences and orders of magnitude of runoff from the La Mercy catchments were reasonably simulated under both bare fallow and sugarcane land cover conditions. In addition, the correlations between observed and simulated runoff volumes were reasonably good as depicted by the regression statistics and the NSE. Under bare fallow conditions, slopes of 
Catchment 101
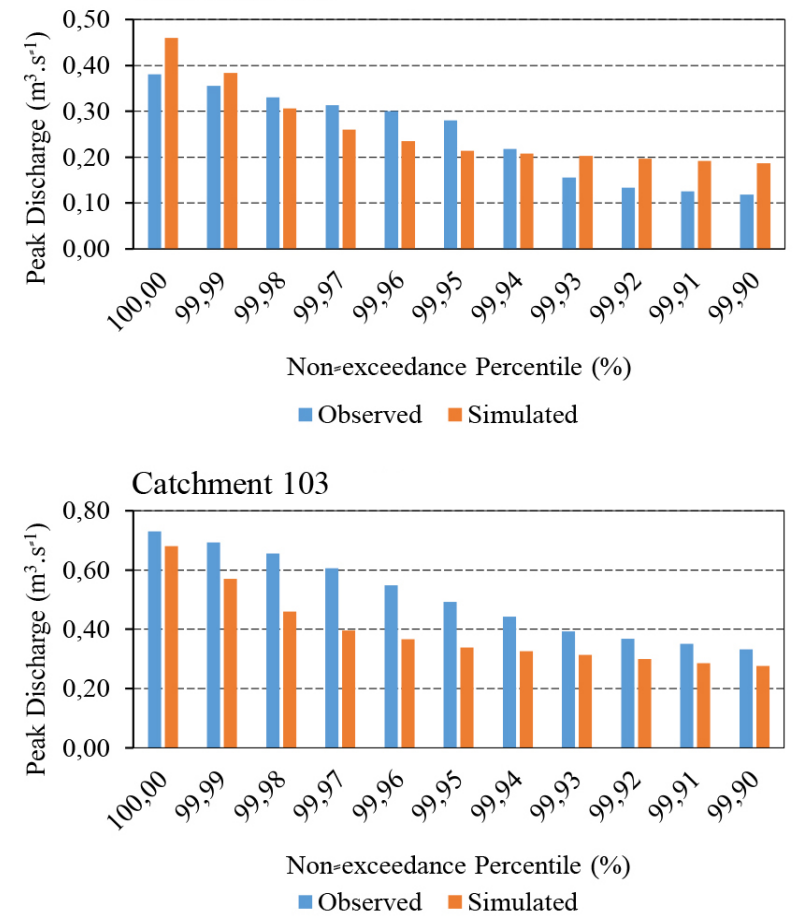

Catchment 102

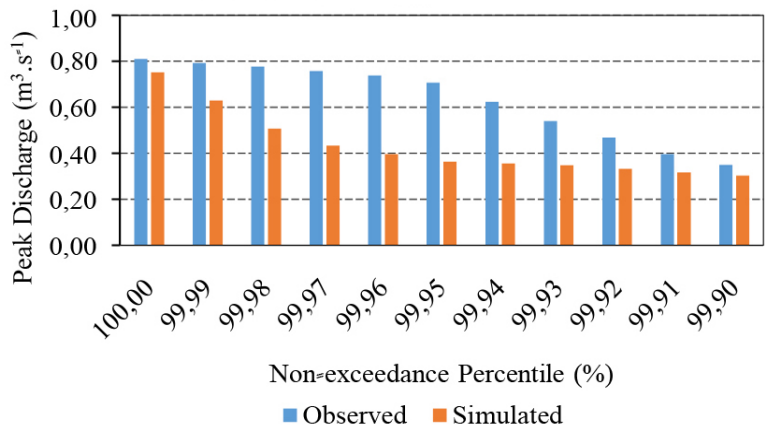

Catchment 104

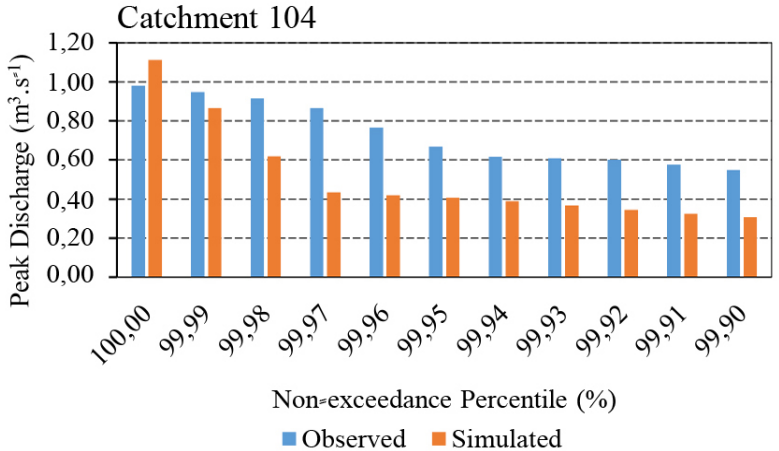

Figure 20. Frequency analysis of daily peak discharge for Catchments 101, 102, 103 and 104

Catchment 101

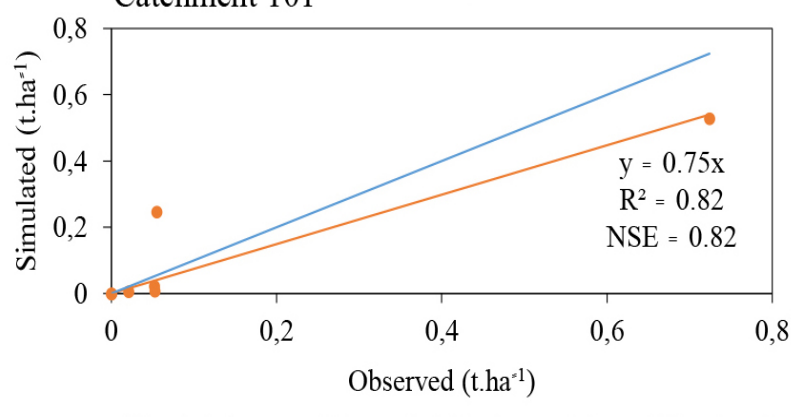

- Simulated — Linear (1:1 line) — Linear (Simulated)

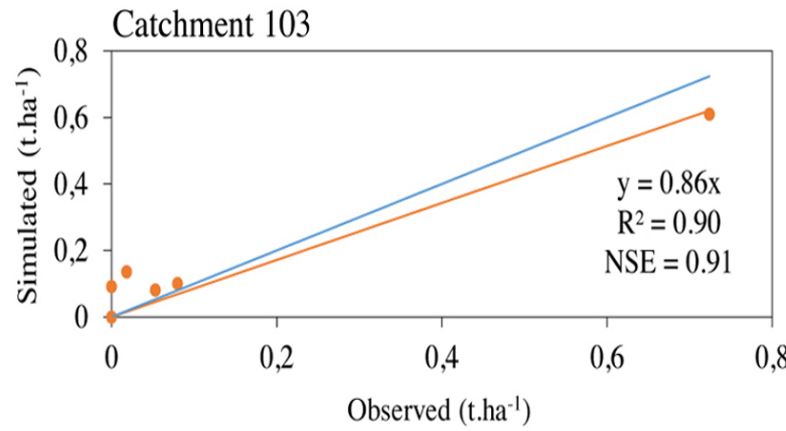

- Simulated — Linear (1:1 line) — Linear (Simulated)

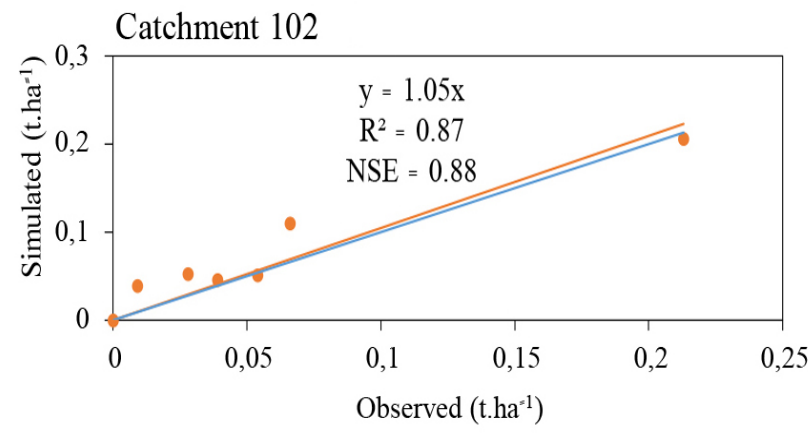

- Simulated — Linear (1:1 line) — Linear (Simulated)

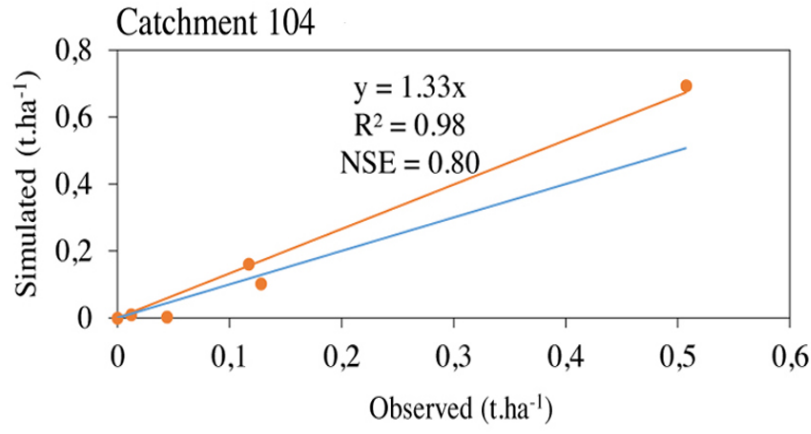

- Simulated — Linear (1:1 line) — Linear (Simulated)

Figure 21. Daily sediment yield simulated from the La Mercy catchments

the regression lines were $0.72,1.09,094$ and 0.54 for Catchments $101,102,103$ and 104, respectively, while the respective $R^{2}$ coefficients were $0.73,0.88,0.89$ and 0.83 . On the other hand, the NSE were $0.73,0.84,0.89$ and 0.73 for Catchments 101, 102, 103 and 104, respectively. For sugarcane land cover conditions, slopes of the regression lines were $1.23,0.90,0.93$ and 0.72 for Catchments 101, 102, 103 and 104, respectively, while the respective $R^{2}$ coefficients were $0.97,0.93,0.94$ and 0.90 . The NSE for Catchments 101, 102, 103 and 104 under similar conditions were $0.89,0.93,0.93$ and 0.87 , respectively. However, over- and under-simulations were evident and these could be attributed to random errors in the measurement of daily runoff volumes, except for Catchment 104 under bare fallow conditions where it is suspected that systematic errors could have occurred in the measurement of daily runoff volumes. 
Table 7. Sediment yield events used in final verification at the La Mercy catchments under sugarcane cover

\begin{tabular}{|c|c|c|c|c|}
\hline Catchment & Date & Observed runoff (mm) & Observed sediment yield $\left(t \cdot h a^{-1}\right)$ & Simulated sediment yield $\left(t \cdot h a^{-1}\right)$ \\
\hline \multirow[t]{7}{*}{101} & 02/11/1985 & 1.3 & 0.72 & 0.53 \\
\hline & 12/03/1986 & 2.4 & 0.02 & 0.01 \\
\hline & 23/03/1987 & 3.1 & 0.05 & 0.01 \\
\hline & 09/05/1988 & 0 & 0.00 & 0.00 \\
\hline & 25/03/1991 & 27.2 & 0.05 & 0.02 \\
\hline & 10/04/1995 & 6.6 & 0.06 & 0.25 \\
\hline & 16/12/1995 & 0.2 & 0.00 & 0.00 \\
\hline \multirow[t]{7}{*}{102} & 02/11/1985 & 0 & 0.21 & 0.21 \\
\hline & 12/03/1986 & 8.9 & 0.03 & 0.05 \\
\hline & 23/03/1987 & 3.3 & 0.07 & 0.11 \\
\hline & 09/05/1988 & 0 & 0.00 & 0.00 \\
\hline & 25/03/1991 & 65.6 & 0.04 & 0.05 \\
\hline & 10/04/1995 & 4.7 & 0.05 & 0.05 \\
\hline & 16/12/1995 & 0.4 & 0.01 & 0.04 \\
\hline \multirow[t]{7}{*}{103} & 02/11/1985 & 0.6 & 0.72 & 0.61 \\
\hline & 12/03/1986 & 5.4 & 0.08 & 0.10 \\
\hline & 23/03/1987 & 1.8 & 0.05 & 0.08 \\
\hline & 09/05/1988 & 0 & 0.00 & 0.00 \\
\hline & 25/03/1991 & 47.2 & 0.02 & 0.14 \\
\hline & 10/04/1995 & 7.7 & 0.00 & 0.09 \\
\hline & 16/12/1995 & 0 & 0.00 & 0.00 \\
\hline \multirow[t]{7}{*}{104} & $12 / 03 / 1986$ & 15.7 & 0.12 & 0.16 \\
\hline & 23/03/1987 & 2.5 & 0.01 & 0.01 \\
\hline & 09/05/1988 & 0 & 0.00 & 0.00 \\
\hline & 25/03/1991 & 57.6 & 0.13 & 0.10 \\
\hline & 10/04/1995 & 22.8 & 0.51 & 0.69 \\
\hline & 22/12/1995 & 19 & 0.00 & 0.00 \\
\hline & 27/12/1995 & 2.8 & 0.04 & 0.00 \\
\hline
\end{tabular}

Simulation and verification of peak discharge was only conducted under sugarcane land cover because there were no observed peak discharge data available under bare fallow conditions. The trends exhibited by simulated daily peak discharges were similar to trends exhibited by simulated daily runoff volumes under each catchment, thereby confirming that runoff volume drives peak discharge. In addition, the association between observed and simulated peak discharge across all four catchments is acceptable, as indicated by the regression statistics. The slopes of the regression lines are 1.01, 0.64, 0.70 and 0.53 for Catchments 101, 102, 103 and 104, respectively, while the respective $R^{2}$ coefficients were 0.82 , $0.78,0.80$ and 0.61 . The NSE for Catchments 101, 102, 103 and 104 were $0.77,0.75,0.78$ and 0.60 , respectively. Nonetheless, incidences of over- and under-simulations were evident and these could be attributed to similar reasons to those cited under verification of runoff volumes.

Similar to daily peak discharge, daily sediment yield was verified under sugarcane land cover conditions because there were no observed sediment yield data available under bare fallow conditions. Due to the fact that various sediment yield records were incomplete, only events documented by Maher (1990), together with a few consistent events, were used in the verifications. The association between simulated and observed sediment yield events was reasonably good. The slopes of the regression lines were $0.75,1.05,0.86$ and 1.33 for Catchments 101 ,
102,103 and 104, respectively, while the respective $R^{2}$ coefficients were $0.82,0.87,0.90$ and 0.98 . The NSE for Catchments 101, 102, 103 and 104 were $0.82,0.88,0.91$ and 0.80 , respectively.

Based on the results of this study, it is concluded that the ACRU model, together with the parameter inputs from the SCDSS and Smithers et al. (1996), are suitable in the simulation of runoff volume, peak discharge and sediment yield from catchments under both bare fallow and sugarcane land cover and with various management practices in South Africa.

In addition, the SCS equation, the Schmidt-Schulze lag equation and the various assumptions and levels of data requirements presented under the verification of daily sediment yield should be employed in simulations of runoff volume, peak discharge and sediment yield. Therefore, the ACRU model can be applied with confidence in the development of updated design norms for soil and water conservation structures in the sugar industry in South Africa.

\section{ACKNOWLEDGEMENTS}

South African Sugarcane Research Institute (SASRI) is gratefully acknowledged for availing resources for this research. Appreciation is also extended Mr SLC Thornton-Dibb for technical guidance on the setting up and application of the ACRU model. 


\section{REFERENCES}

AGRIMETSOFT (2019) Online calculators. https://agrimetsoft. com/calculators/Nash\%20Sutcliffe $\% 20$ model\%20Efficiency $\% 20$ coefficient: (Accessed 01 January 2020).

HARMEL R, SMITH P, MIGLIACCIO K, CHAUBEY I, DOUGLASMANKIN K, BENHAM B, SHUKLA S, MUÑOZ-CARPENA R and ROBSON BJ (2014) Evaluating, interpreting, and communicating performance of hydrologic/water quality models considering intended use: A review and recommendations. Environ. Model. Softw. 57 40-51. https://doi.org/10.1016/j.envsoft.2014.02.013

HAYWOOD RW (1991) Model evaluation for simulating runoff from sugarcane fields. MScEng Dissertation, University of Natal Pietermaritzburg, RSA.

HUI-MING S and YANG CT (2009) Estimating overland flow erosion capacity using unit stream power. Int. J. Sediment Res. 24 (1) 46-62. https://doi.org/10.1016/S1001-6279(09)60015-9

JEWITT GPW and SCHULZE RE (1999) Verification of the ACRU model for forest hydrology applications. Water SA 25 (4) 483-490.

KIM K, WHELAN G, PURUCKER ST, BOHRMANN TF, CYTERSKI MJ, MOLINA M, GU Y, PACHEPSKY Y, GUBER A and FRANKLIN DH (2014) Rainfall-runoff model parameter estimation and uncertainty evaluation on small plots. Hydrol. Process. 28 (20) 5220 5235. https://doi.org/10.1002/hyp.10001

LORENTZ SA and SCHULZE RE (1995) Sediment yield. In: Schulze RE (ed.) Hydrology and Agrohydrology: A Text to Accompany the ACRU 3.00 Agrohydrological Modelling System. Department of Agricultural Engineering, University of Natal, Pietermaritzburg, RSA.

LUMSDEN TG, JEWITT GPW and SCHULZE RE (2003) Modelling the impacts of land cover and land management practices on stream flow reduction. WRC Report No. 1015/1/03. Water Research Commission, Pretoria. $80 \mathrm{pp}$.

MACVICAR CN, DE VILLIERS JM, LOXTON RF, VERSTER E, LAMBRECHTS JJN, MERRYWEATHER FR, LE ROUX J, VAN ROOYEN TH and HARMSE HJVM (1977) Soil classification. A binomial system for South Africa. Department of Agricutural Development, Pretoria. .

MAHER GW (1990) Phase two of the small catchment project at La Mercy. In: Proceedings of South Africa Sugar Technologists' Association, June 1990, Durban, RSA.

MAHER GW (2000) Research into soil and water losses from sugarcane fields in South Africa - A review. In: Int Soc Sug Cane Technol Agronomy Workshop, December 2000, Miami, USA

MERRITT WS, LETCHER RA and JAKEMAN AJ (2003) A review of erosion and sediment transport models. Environ. Model. Softw. 18 (8) 761-799. https://doi.org/10.1016/S1364-8152(03)00078-1

MORGAN RPC (2005) Soil Erosion and Conservation. Blackwell Publishing, Malden. 304 pp.

NASH JE and SUTCLIFFE JV (1970) River flow forecasting through conceptual models: part I. A discussion of principles. J. Hydrol. 10 (3) 282-90. https://doi.org/10.1016/0022-1694(70)90255-6

OTIM D (2018) Development of updated design norms for soil and water conservation structures in the sugar industry of South Africa. PhDEng draft thesis, School of Engineering, University of KwaZuluNatal, Pietermaritzburg.

PLATFORD GG (1987) A new approach to designing the widths of panels in sugarcane fields. In: Proceedings of South Africa Sugar Technologists' Association, June 1987, Mount Edgecombe, RSA.

PLATFORD GG (1988) Protection against flood damage. In: Proceedings of South Africa Sugar Technologists' Association, June 1988, Durban.

PLATFORD GG and THOMAS CS (1985) The small catchment project at La Mercy. In: Proceedings of South Africa Sugar Technologists' Association, June 1985, Durban.

RASHID MM, BEECHAM S and CHOWDHURY RK (2015) Statistical characteristics of rainfall in the Onkaparinga catchment in South Australia. J. Water Clim. Change 6 (2) 352-373. https://doi. org/10.2166/wcc.2014.031

ROWE TJ (2015) Development and assessment of rules to parameterise the ACRU model for design flood estimation. MScHydrology dissertation, Pietermaritzburg, RSA

ROYAPPEN M (2002) Towards improved parameter estimation in streamflow predictions using the ACRU model. MScHydrology dissertation, Pietermaritzburg, RSA

SASRI (1998) Information Sheet 4.10: Minimum tillage. SASEX, Mount Edgecombe, RSA.

SCHMIDT EJ and SCHULZE RE (1984) Improved estimates of peak flow rates using modified SCS lag equations. WRC Report No. TT 31/87. Water Research Commission, Pretoria. 145 pp.

SCHMIDT EJ, SCHULZE RE and DENT MC (1987) Flood volume and peak discharge from small catchments in Southern Africa based on the SCS technique. WRC Report No. TT 31/87. Water Research Commission, Pretoria. 164 pp.

SCHULZE RE (1975) Catchment evapotranspiration in the Natal Drakensberg. PhD thesis, University of Natal, Pietermaritzburg.

SCHULZE RE (1995) Streamflow. In: Schulze RE (ed.) Hydrology and Agrohydrology: A Text to Accompany the ACRU 3.00 Agrohydrological Modelling System. Department of Agricultural Engineering, University of Natal, Pietermaritzburg.

SCHULZE RE (2011) A 2011 Perspective on climate change and the South African water sector. WRC Report No. 1843/2/11. Water Research Comission, Pretoria. 366 pp.

SCHULZE RE, ANGUS GR, LYNCH SD and SMITHERS JC (1995) ACRU: Concepts and structure. In: Schulze RE (ed.) Hydrology and Agrohydrology: A Text to Accompany the ACRU 3.00 Agrohydrological Modelling System. Department of Agricultural Engineering, University of Natal, Pietermaritzburg.

SCHULZE RE and SCHMIDT EJ (1995) Peak discharge. In: Schulze RE (ed.) Hydrology and Agrohydrology: A Text to Accompany the ACRU 3.00 Agrohydrological Modelling System. Department of Agricultural Engineering, University of Natal, Pietermaritzburg.

SCHULZE RE, SCHMIDT EJ and SMITHERS IC (1992) PC based SCS design flood estimates for small catchments in Southern Africa. ACRU Report 40. Department of Agricultural Engineering, University of Natal, Pietermaritzburg. $47 \mathrm{pp}$

SCHULZE RE, SCHMIDT EJ and SMITHERS JC (2004) Visual SCS SA User Manual Version 1.0: PC based SCS design flood estimates for small catchments in Southern Africa. ACRUcons Report No. 52. School of Bioresources Engineering and Environmental Hydrology, University of KwaZulu-Natal, Pietermaritzburg.

SCHULZE RE and SMITHERS JC (1995) Procedures to improve and verify streamflow simulations. In: Smithers JC and Schulze RE (ed.) ACRU Agrohydrological Modelling System: User Manual Version 3.00. Department of Agricultural Engineering, University of Natal, Pietermaritzburg.

SMITHERS J and SCHULZE R (1995) ACRU Agrohydrological Modelling System User Manual. Department of Agricultural Engineering, University of Natal, Pietermaritzburg, RSA. 374 pp.

SMITHERS JC, MATHEWS P and SCHULZE RE (1996) The simulation of runoff and sediment yield from catchments under sugarcane production at La Mercy. ACRUcons Report No. 13. Department of Agricultural Engineering, University of Natal, Pietermaritzburg. $104 \mathrm{pp}$.

TANYAŞ H, KOLAT Ç and SÜZEN ML (2015) A new approach to estimate cover-management factor of RUSLE and validation of RUSLE model in the watershed of Kartalkaya Dam. J. Hydrol. 528 584-598. https://doi.org/10.1016/j.jhydrol.2015.06.048

WILLIAMS JR (1975) Sediment-yield prediction with universal equation using runoff energy factor. In: ARS-S (ed.) Present and Prospective Technology for Predicting Sediment Yields and Sources. Southern Region, Agricultural Research Service, U.S. Department of Agriculture, New Orleans, USA.

WISCHMEIER WH and SMITH DD (1965) Rainfall erosion losses from cropland east of the rocky mountains. In: Guide for Selection of Practices for Soil and Water Conservation. Agricultural Handbook No. 282. USDA, Washington D.C.

WISCHMEIER WH and SMITH DD (1978) Predicting Rainfall Erosion Losses - A guide to Conservation Planning. USDA, Washington D.C., USA. 63 pp. 